\title{
The Poverty of Theory Revisited \\ Or, Critical Theory, Historical Materialism, And The Ostensible End Of Marxism
}

\section{Bryan D. Palmer}

It is now a decade-and-one-half since Edward Thompson penned "The Poverty of Theory: or an Orrery of Errors," and ten times that amount of time has passed since the publication of Marx's The Poverty of Philosophy. ${ }^{1}$ Whatever one may think about the advances in knowledge associated with historical materialism and Marx:sm, particularly in terms of the practice of historical writing, there is no denying that this sesquicentennial has been a problematic period in the making of communist society; the last fifteen years, moreover, are associated with the bleak end of socialism and the passing of Marxism as an intellectual force.

Indeed, it is a curious conjuncture of our times that the much-proclaimed end of Marxism is somehow related to the end of history as we know it. Who would have thought that history, both as an unfolding process and a set of interpretive writings, would come to an end when Marxism as a ruling ideology in what has passed for 'socialist' political economies crumbled and lost its appeal to many academics? No Marxist ever accorded his or her world view the apparent force or influence - in theory or practice - that this current coupled understanding of the early 1990s end of Marxism/history suggests. ${ }^{2}$

For those who revel in the discursive identities and endlessly fluctuating subjectivities of poststructuralism as theory and postmodernism as condition, the instabilities of the current moment - analytical and political - are absolute advantages, realities in an age that refuses acknowledgement of 'the real', substance to be celebrated and championed in times when resistance has been thankfully replaced by play and pun. To be a Marxist in these times is obviously neither easy nor pleasant, but it does offer certain securities. Among the most significant, perhaps, is the insight that what we are witnessing now, however seemingly novel and debilitating, has parallels and, perhaps, direct precedent in past struggles over questions of theory and interpretation, battles that were seldom divorced from that touchstone of the human condition, history. "With man we enter history," proclaimed Engels. ${ }^{4}$

And yet if we are to appreciate current intellectual trends, it is apparent that history is precisely what is not being 'entered'. This essay takes as its central concern the extent to which a rather uncritical adoption of what has come to be known as critical theory has resulted in the wholesale jettisoning of historical materialist assumptions

1 E. P. Thompson, The Poverty of Theory \& other essays (London 1978); Karl Marx, The Poverty of Philosophy; Answer to the 'Philosophy of Poverty' by M. Proudhon (Moscow n.d., original 1847).

2 Associated with the much-publicized 1989 pronouncement of Francis Fukuyama that "What we may be witnessing is not just the end of the Cold War, or the passing of a particular period of postwar history, but the end of history as such," this position has gained much credence. For a journalistic statement see Richard Bernstein, "Judging 'Post-History', the End to All Theories," New York Times, 27 August 1989. Responses from the Marxist left include the essays in Ralph Miliband, Leo Panitch, and John Saville, ed., The Retreat of the Intellectuals: Socialist Register 1990 (London 1990).

3 Note, for instance, the argument in Ellen Meiksins Wood, The Retreat from Class: A New 'True' Socialism (London 1986).

4 Frederick Engels, "Introduction to Dialectics of Nature," in Marx and Engels, Selected Works (Moscow 1968), 353. 
and understandings, to the detriment of historical sensitivities and the denigration of the actual experience of historically-situated men, women, and children. Those proclaiming the end of history actually aim to end much more; the implications of this purpose are quite striking and equally startling. To make this claim is not to suggest that there can be no engagement with this critical theory and that it has nothing to tell us. Rather, this ground of refusal can be claimed for Marxism and historical materialism precisely because the value of critical theory can be assimilated, enriching historical investigation and interpretation, but only if the cavalierly unthinking and patently ideological anti-Marxism so pervasive among former leftists in the 1990 s is identified and rejected for what it is: the opportunism and apostasy of a particular political climate ${ }^{5}$ Norman Geras has had the temerity to actually designate this a process of personal retreat, and in the process question acutely its rationalizations, so commonplace in the $1990 \mathrm{~s}$ :

In the advanced capitalist world from the mid-1960s a generation of intellectuals was radicalized and won for Marxism. Many of them were disappointed in the hopes they formed - some of these wild but let that pass - and for a good while now we have been witnessing a procession of erstwhile Marxists, a sizeable portion of the generational current they shared in creating, in the business of finding their way 'out' and away. This exit is always presented, naturally, in the guise of an intellectual advance. Those of us unpersuaded of it cannot but remind its proponents of what they once knew but seem instantly to forget as they make their exit, namely, that the evolution of ideas has a social and material context. We cannot help wondering how far their recent trajectory may have been influenced by a range of factors which they themselves would doubtless prefer to overlook: the pressures upon them of age and professional status; the pressures of the political time and environment we have been passing through, not very congenial, in the West at least, to the sustenance of revolutionary ideas; and then the lure of intellectual fashion, a consideration not to be underrated by any means. ${ }^{6}$

This essay proceeds in particular directions. First, it notes briefly the extent to which poststructuralism and postmodernism have generally espoused a particular hostility to historical materialism ${ }^{7}$ and, in identifying this hostility, it provides indications of what the theoretical literature in these areas espouses and contributes to a potentially analytic historiography. In this brief definitional and descriptive preface there will be occasion to comment on the nature of the relationship of poststructuralism/postmodernism and Marxism, especially the validity and quality of much of critical theory's dismissal of historical materialism. Second, a short pause will be taken to allude to previous historical moments, from The Poverty of Philosophy to "The Poverty of Theory," in an effort to illuminate that positions promoted as avant-garde and 'post'modern are in fact often rather old politico-intellectual hat. Third, contemporary developments in historiography related to the critical theory of the 1980s and 1990s will be addressed, and a critique of arguments dismissive of historical materialism elaborated. An attempt will be made to explore the contempo-

5 Again, this has historical parallels. See E. P. Thompson, "Outside the Whale," in The Poverty of Theory, 1-34; Thompson, "Disenchantment or Default? A Lay Sermon," in Conor Cruise O'Brien and W. D. Vanech, ed., Power and Consciousness (New York 1969), 149-181.

6 Norman Geras, Discourses of Extremity: Radical Ethics \& Post-Marxist Extravagances (London $1990), 62$.

7 Fredric Jameson notes "One's occasional feeling that, for poststructuralism, all enemies are on the left, and that the principal target always turns out to be this or that form of historical thinking...." Jameson, Postmodernism: or, the Cultural Logic of Late Capitalism (Durham, North Carolina 1991), 217. 
rary relevancy of Marxist historical analysis and its capacity to actually ground the often important insights of critical theory in materially embedded social relations and experiences of struggle and subordination, power and resistance, accumulation and accommodation. Fourth, and finally, the essay closes with an explanation of the ironies and potency of an anti-Marxist critical theory in the context of the 1990s.

\section{Ideology and Epoch}

Ideology, as Terry Eagleton has recently reminded us, is a complex term with an even more complicated historical evolution. ${ }^{8}$ It is also rather suspect in most intellectual circles at the moment, a process of denigration that Eagleton notes is not unrelated to the current fashion of poststructuralist thought and the contemporary assumptions and trends of postmodernity as a peculiarly distinct fin-de-siècle. It is nevertheless useful, both in terms of situating poststructuralism and postmodernism as particular meanings in the present of the 1990s and in locating them historically, to adopt a conception of ideology drawn from those who both founded historical materialism and inaugurated modern understanding of ideology as a central category in the linked projects of interpreting and changing the world.

At the risk of sliding over many qualifications and eliding not a few problematic writings, Marx and Engels nevertheless developed an appreciation of ideology as a material constraint on the possibility of revolution. As in much of the elaboration of the concepts of historical materialism, their method was polemical, a striking out at what was inadequate and ideological in the philosophical conventions of their time. Against the idealized advances of Enlightenment thought (which marked a turning point away from blind obedience to superstition, illusion, and divine authority), Marx and Engels propounded a radicalized extension of Enlightenment reason, insisting not on the liberatory potential of dehistoricized ideas and abstractions, but rather on the powerful determination of profane social activity. In The German Ideology Marx and Engels assailed as ideological the idealism that refused acknowledgement of the primacy of actual humanity, the determining power of social relations over the consciousness of those relations:

The premises from which we begin are not arbitrary ones, not dogmas, but real premises from which abstraction can only be made in the imagination. They are the real individuals, their activity and the material conditions under which they live, both those which they find already existing and those produced by their activity.... The writing of history must always set out from these natural bases and their modification in the course of history through the action of man.... Consciousness can never be anything else than conscious existence, and the existence of men is their actual life-process. If in all ideology men and their circumstances appear upside down as in a camera obscura, this phenomenon arises just as much from their historical lifeprocess as the inversion of objects on the retina does from their physical life-process.... Life is not determined by consciousness, but consciousness by life.

For Marx and Engels, then, ideology was originally and fundamentally the construction of false consciousness, the obscuring of the primacy of social practice, and the reification of ideas and categories as ruling forces in history. Much muddled in later years, as the term came to be associated with varied meanings associated with different movements and personalities of revolutionary opposition, ideology's tan-

8 See Terry Eagleton, Ideology: An Introduction (London 1991).

9 Karl Marx and Frederick Engels, The German Ideology (New York 1947), 6-7, 14-15. 
gled history as a concept parallels the history of Marxism: relatively coherent throughout the years of the Second International, it fragments in the aftermath of World War I. ${ }^{10}$

It is the fundamental premise of this essay that poststructuralism is the ideology of a particular historical epoch now associated with postmodernity. Alex Callinicos has recently argued, with considerable conviction and force, that postmodernity does not exist as some sharp and fundamental break from 'the modern', a scepticism also at the core of Marshall Berman's exploration of the experience of modernity. ${ }^{11}$ They may be right, although for the purposes of this essay the matter is somewhat beside the point. It is perfectly plausible to accept that the late twentieth century has witnessed a series of shifts in the cultural arena, even perhaps in the realm of political economy, without, of course, seeing this as a fundamental transformation of the mode of production. Many sites of 'representation' and related fields of 'design', by which the spatial and cultural aspects of our lives are ordered through the reconstruction of modernism's locale, the urban landscape, can be scrutinized in ways that suggest recent change in literary genres, art and architecture, cinema, and the technology of cultural diffusion, the case of video being undoubtedly the most dramatic. I see no necessity to deny that all of this means something culturally and is related to material structural transformation, most markedly the rise and fall of what some social theorists designate a Fordist regime of capitalist accumulation. ${ }^{12}$ Contra Callinicos (who does strike some telling blows) are the resolutely historicized and materialist recent texts of Frederic Jameson and David Harvey. Taken together, Jameson's Postmodernism; or, the Cultural Logic of Late Capitalism and Harvey's The Condition of Postmodernity: An Enquiry into the Origin of Cultural Change present a complementary account of the remaking of a capitalist cultural order in the late twentieth century. But unlike most postmodernists, these Marxists refuse to see this restructuring of fundamental features of the non-biological reproductive realm as a remaking of the capitalist mode of production. Postmodernity, for Jameson and Harvey, whatever differences in emphases they choose to accentuate, is an epoch of capitalism, as fundamentally continuous with the exploitation and accumulation of earlier times as it is discontinuous in its forms of representational expression. ${ }^{13}$ And like the Los Angeles of Mike Davis's City of Quartz, this postmodernity as capitalist condition is made, not outside of history, but inside its relations of power and challenge, struggle and subordination. ${ }^{14}$

What a Marxist reading of postmodernism rejects, then, is not the condition of contemporary cultural life, which, admittedly, is open to many contending historical materialist readings, one of which might well lay stress on the cultural movement into postmodernity. Rather, Marxism rejects the ideological project of rationalizing and legitimating this postmodern order as something above and beyond the social

10 For an overly brief statement see the entry on "ideology" in Tom Bottomore, ed., A Dictionary of Marxist Thought (Cambridge, Massachusetts 1983), 219-223.

11 Alex Callinicos, Against Postmodernism: A Marxist Critique (New York 1990); Marshall Berman, All That Is Solid Melts Into Air: The Experience of Modernity (New York 1982).

12 See, among other writings, Mike Davis, Prisoners of the American Dream: Politics and Economy in the History of the US Working Class (London 1986).

13 Fredric Jameson, Postmodernism; or, the Cultural Logic of Late Capitalism (Durham, North Carolina 1991); David Harvey, The Condition of Postmodernity: An Enquiry into the Origins of Cultural Change (Oxford 1989). For comment on these texts see Bryan D. Palmer, "The Condition of Postmodernity and the Poststructuralist Challenge to Political and Historical Meaning," forthcoming, The Maryland Historian (1992).

14 Mike Davis, City of Quartz: Excavating the Future in Los Angeles (London 1990). 
relations of a capitalist political economy. In the words of the American advocate of poststructuralism, Mark Poster, this notion of postmodernism is not unrelated to the dismissal of Marxism:

In the first half of the twentieth century marxist theory suffered three setbacks: (1) the establishment of bureaucratic socialism in Eastern Europe; (2) the rise of fascism in Central Europe; and (3) the birth of the 'culture industry' in Western Europe and the United States. These massive phenomena reshuffled the dialectical deck of cards. No longer could it be said that the working class is the standard-bearer of freedom, the living negation of domination, the progressive side in the contemporary class struggles that would surely end in a utopian community.

For poststructuralists such as Poster these 'truths' (which, it must be pointed out, are eminently explainable through Marxist theory and have not shaken Marxism as a project of understanding) are only reinforced by even more recent events and developments:

Today in the late twentieth century the situation has grown worse.... (1) the decolonization movement has raised voices that question the ability of Western thought to encompass the critique of Western forms of domination; (2) the feminist movement has uncovered patriarchal elements within Western theory, not excepting critical theory; (3) the social formation has been altered by electronic systems of communication, cybernetic devices, and a massive institutional growth of science, changes I lump together under the designation 'mode of information'. Albeit in very different ways, each of these developments calls into question not only the familiar social landscape...but the subject of that theory - the position of the knower, the assumptions of the theorist that authorized him/her to write, that governed the shape of his/her discourse, that provided certain unexamined suppositions about the world, about writing, and about the relation of writing to the world. ${ }^{15}$

In passages such as these, the making of poststructuralism as an ideological reaction to the failures of what was once a Stalinized actually existing socialism are exposed and the trajectory and constellation of a new ideology in the making clarified: as the working class is arbitrarily and conceptually displaced as the agent of social transformation, a seemingly unassailable dismissal following logically from the degeneration of the first workers state, Marxism is overtaken by both its own political failures and the arrival of new social forces (the feminist and decolonization movements, to which could be added other sectors: peace, ecology, aboriginal and 'national' rights) and social formations, none of which are situated concretely in anything approximating an elementary relationship to actually existing capitalism. In the process any sense of objective 'reality' and its social relations is lost in the swirl of subjectivity that forces a retreat from class and an embrace of almost any and all other 'identities', which are understood as expansive, discursive, and positively plural. It is the contention of this essay that poststructuralism is thus a project of mystification and obfuscation particularly attuned to the often submerged, occasionally explicit, politics of the moment; poststructuralism as theory is to postmodernity as epoch what idealism as philosophy was to the Enlightenment. This does not mean that it contains no insights or potential, only that left to its own ultimatist trajectory it will inevitably collapse into ideology.

What is poststructuralism? What is this new critical theory? This is a large question, the answering of which demands an understanding of much of the intellec-

15 Mark Poster, Critical Theory and Poststructuralism: In Search of a Context (Ithaca and London 1989), 1-3. 


\section{2 left history}

tual history of the last century. ${ }^{16}$ But, bluntly put, poststructuralism emerged out of the theoretical implosions associated with Parisian intellectual life in the 1960s, most particularly 1968. By that date a French theoretical turn had concentrated the social anthropology of Claude Lévi-Strauss, Lacanian psychoanalysis, and a textuallyfocussed Althusserian Marxism in a paradigm known as structuralism. What united these components of the French theoretical turn was a deep commitment to a scientific explication of the structural systems of human existence. In the cases of Lévi-Strauss and Lacan, interpretation of these structural systems was explicitly scaffolded on insistence that language was the foundation of all human activity, which was therefore understandable only in terms of the laws of linguistics as propounded by Saussure. From kinship systems to the unconscious, structuralism proclaimed a linguistic apprehension of reality. "All the anthropologist can do is say to his colleagues in other branches of study that the real question is the question of language," claimed Lévi-Strauss. "If you solve the problem of the nature and origin of language, we can explain the rest: what culture is, and how it made its appearance; what art is and what technological skills, law, philosophy and religion are."17 For his part, Lacan "Saussureanized" psychoanalysis, declaring that "the unconscious is the discourse of the other...the symptom resolves itself entirely in a Language analysis, because the symptom itself is structured like a Language, because the symptom is a Language from which the Word must be liberated." 18 This linguistic scientism scorched Parisian Marxism in the 1960s, culminating in what Thompson and Norman Geras dubbed "the final idealism" of Althusser. ${ }^{19}$ In the Althusserian reading of ideology "the only interests at work in the development of knowledge are interests internal to knowledge." 20

The making of the French structuralist turn was thus propelled by the reification of language, a process that quite conveniently divorced humanity from history. For Lévi-Strauss history was little more than, "that irreducible contingency without which necessity would be inconceivable." Interpretation gained nothing from submitting itself to "the powerful inanity of events," for history could "lead to anything, provided you get out of it." ${ }^{21}$ When the French turn took its Marxist detour, Althusser and his advocates occasionally found themselves on this same slippery slope of the repudiation of historical materialism.

With the Parisian events of 1968 a curtain descended on the analytic stage of structuralism. Its players experienced a certain banishment. With them went various projects - the Lévi-Straussian imposition of classifications and order, the Lacanian stress on the historicized subject, the Althusserian insistence on ideology's rootedness in class interests - although the swept stage, now occupied by poststructuralism, remained littered with the residue of structuralism, most particularly language as the

16 I have attempted to offer a brief overview of some of the salient intellectual developments in Descent into Discourse: The Reification of Language and the Writing of Social History (Philadelphia 1990), 3-47.

17 G. Charbonnier, Conversations with Claude Lévi-Strauss (London 1973), 154-55.

18 See, for instance, Jacques Lacan, Speech and Language in Psychoanalysis, translated by Anthony Wilden (Baltimore 1968), esp. 7-8, 27, 32.

19 Thompson, "The Poverty of Theory"; Norman Geras, "Althusser's Marxism: An Assessment," in New Left Review, ed., Western Marxism: A Critical Reader (London 1978), 232-272.

20 Geras, "Althusser's Marxism," 266, 268.

21 Claude Lévi-Strauss, From Honey to Ashes: Introduction to a Science of Mythology, Volume 2 (New York 1973), 475; Lévi-Strauss, The Savage Mind (Chicago 1973), 262; Lévi-Strauss, The Scope of Anthropology (London 1971), esp. 24-25. 
site of meaning, power, and resistance. Eagleton portrays the new poststructuralist scene:

Post-structuralism was a product of that blend of euphoria and disillusionment, liberation and dissipation, carnival and catastrophe, which was 1968. Unable to break the structures of state power, post-structuralism found it possible instead to subvert the structures of language....The student movement was flushed off the streets and driven underground into discourse...the system had proved too powerful...and the 'total' critique offered of it by a heavily Stalinized Marxism had been exposed as part of the problem, not the solution. All such total systematic thought was now suspect as terroristic: conceptual meaning itself, as opposed to libidinal gesture and anarchist spontaneity, was feared as repressive. ...The only forms of political action now felt to be acceptable were of a local, diffused, strategic kind: work with prisoners and other marginalized social groups, particular projects in culture and education. The women's movement, hostile to the classical forms of left-wing organization, developed libertarian, 'decentred' alternatives and in some quarters rejected systematic theory as male. For many post-structuralists, the worst error was to believe that such local projects and particular engagements should be brought together within an overall understanding of the working of monopoly capitalism, which could only be as oppressively 'total' as the very system it opposed. ${ }^{22}$

Poststructuralism was thus born of structuralism's demise. It carried a part of structuralism's legacy, most acutely in terms of the stress on language, but it refused many of structuralism's assumptions and purposes. In the writings of Michel Foucault, Jacques Derrida, Jean Baudrillard, Gilles Deleuze, and Jean-François Lyotard a reevaluation of language and its meanings culminated in an intense interrogation of 'the real', a relentless exposure of the ways in which knowledge/reason masked domination, and a blunt rejection of any and all projects - emancipatory or otherwise - that sought to impose or locate centres of power or resistance. To the structuralist interpretive order was orchestrated, a conscious construction of the human mind. For the poststructuralist, however, such order/orchestration was to be deconstructed. In the words of Derrida, drawing upon Montaigne, the poststructuralist project was "to interpret interpretations more than things," a constant unravelling of language that easily slipped into a positioning that "everything became [or was] language." History, for Derrida, has always been conceived as but "a detour between two presences." ${ }^{23}$

Poststructuralist thought is extremely difficult to pin down and define with clarity precisely because it celebrates discursiveness, difference, and destabilizations: it develops, not as a unified theory, but as constantly moving sets of concentric circles, connected at points of congruence, but capable of claiming new and uncharted interpretive territory at any moment. Like the architectural innovations of the postmodern age, poststructuralist theory is defiant of boundaries, resists notions of the analytic equivalent of a spatial centre in the celebration of discursiveness and proliferating subjectivities, and elevates the untidy to a virtue in a principled refusal of causality. Poststructuralism thus rationalizes, legitimizes, and indeed sanctifies the postmodern condition. Its role as ideology secures the present; in the process it severs this present from the past and limits the possibilities of its future.

In its beginnings, one of poststructuralism's attractions was undoubtedly what Callinicos has referred to as its "openness to the contingencies, the uncertainties, the instabilities of history." ${ }^{24}$ But ideologies, always dependent on their capacity to

22 Terry Eagleton, Literary Theory: An Introduction (Minneapolis 1983), 142.

23 Note, especially, the important article, Jacques Derrida, "Structure, Sign, and Play in the Discourse of the Human Sciences," in Derrida, Writing and Difference (Chicago 1978), 279-280, 291-292. 


\section{4 left history}

illuminate a part of experience at the same time as they mystify it, have a tendency to overreach themselves in moments of extremist overconfidence. Postmodernity, an age of excess if there ever was one, pushes ideology masquerading as theory in precisely this direction.

This point has recently been made with great force in Robert Young's insistence that history has never been anything but problematic in as much as it has always been an outcome of imperialistic plunder and the subordination of specific peoples of colour. Drawn to the 'postcolonialist' wing of critical theory, Young regards 'History' as but one expression of the Eurocentric premises of Western knowledge, a flattened exercise in shoring up "the concept, the authority, and assumed primacy of, the category of 'the West'." He finds great solace in poststructuralism's questioning of history - which, abstractly, poses no problem for historical materialism, engaged as it is in the same project - and, more to the point, in postmodernism's achievements in precipitating us into a period of dissolution:

Contrary, then, to some of its more overreaching definitions, postmodernism itself could be said to mark not just the cultural effects of a new stage of 'late' capitalism, but the sense of the loss of European history and culture as History and Culture, the loss of their unquestioned place at the centre of the world. We could say that if...the centrality of 'Man' dissolved at the end of the eighteenth century as the 'Classical Order' gave way to 'History', today at the end of the twentieth century, as 'History' gives way to the 'Postmodern', we are witnessing the dissolution of the 'West' ${ }^{25}$

The problem with this passage, and the book of which it is a part, is not that it alerts us to the need to scrutinize the making of history in ways sensitive to colonialism and its immense human costs. Rather, the difficulty with Young's deconstruction of 'history' is its partial, amazingly self-selecting account of what constitutes the text of a highly differentiated historical practice: Toynbee, Trotsky, and E.P. Thompson are at least alluded to once or twice (although, amazingly, Victor Kiernan merits nary a nod), but only in passing, and in ways that homogenize historiographies designated 'white'; C.L.R. James, Walter Rodney, and Jean Chesneaux are absent from this account, allowing Young to bypass histories made at particular points of intersection, in which First and Third Worlds meet and white, black, brown, and yellow connect.

To be sure, Young's poststructuralist assault on History contains the kernel of challenge attractive to many who want to right the wrongs of a historiography rooted in racism. But it does so in ways that actually stifle the project of emancipation, suffocating it in an ideology of illusion. For the 'West', as the site of capitalism's late twentieth-century power, is not, in any meaningful sense, in the throes of dissolution. Whatever the cultural reconstructions of postmodernity as a period of capitalist accumulation, 'History' has hardly been displaced. Mere months after the publication of Young's words, the carnage of the Gulf War exposed the Achilles Heal of this kind of ideological trumpeting to the unequivocal and technologically superior blows of a 'West' as bellicose and militantly militaristic as other, ostensibly long-buried capitalist social formations. Small wonder that Marxists such as Ellen Meiksins Wood, attentive to the history of capitalism, have thrown up their hands in despair at what poststructuralism as ideology has accomplished in a few short years. "At the very moment when the world is coming ever more within the totalizing logic of capitalism and its homogenizing impulses, at the very moment when we have the greatest need for conceptual tools to apprehend that global totality," protests Wood,

24 Alex Callinicos, Making History: Agency, Structure and Change in Social Theory (Ithaca 1988), 3.

25 Robert Young, White Mythologies: Writing History and the West (London 1990), esp. 20. 
"the fashionable intellectual trends, from historical 'revisionism' to cultural 'postmodernism', are carving up the world into fragments of 'difference'."26

My sympathies obviously lie with. Wood, and with a host of other Marxist and feminist commentary that has grappled with the rise of poststructuralism, but that is almost universally ignored by those championing the new critical theory. ${ }^{27}$ This is not to say that Marxists need ignore the extent to which poststructuralist thought forces our sometimes partially-closed eyes open to specific problems that have received perhaps less than adequate attention within the many streams of a highly variegated Marxist tradition, including the very 'difference' Wood seems to castigate. The importance of subjectivity and the self, of identities not reducible to class, of representation and discourse, of the problematic ambivalence of 'knowledge' canonized within particular social formations where thought and power are not unrelated - all of which poststructuralism alerts us to even as it overdetermines analysis of this terrain off of its material referents — need not be denigrated by Marxists. Indeed, it is possible to actually explore specific texts of historical materialism to make the point that attention to discourse, even to the point of materializing it and exploring its role in determination, is not necessarily foreign to the Marxist project. ${ }^{28}$ But this kind of serious reading of Marxist histories is often the furthest thing from the poststructuralist mind, which prefers, oddly enough given its categorical hostility to binary oppositions, an oppositional relation to Marxism founded in what Norman Geras has called "conceptual absolutism."29

Thus, the highly influential Ernesto Laclau and Chantal Mouffe rethink socialist politics out of a view of Marxism that is little more than a rhetorical parody stringing together categories that seem so outlandish precisely because, in their ludicrous progression, they conjure up a commonsensical - if undeniably bourgeois counterpoint of binary oppositions: "What is now in crisis," we are told barely a page into Hegemony and Socialist Strategy, "is a whole conception of socialism which rests upon the ontological centrality of the working class, upon the Role of Revolution, with a capital ' $r$ ', as the founding moment in the transition from one type of society to another, and upon the illusory prospect of a perfectly unitary and homogeneous collective will that will render pointless the moment of politics." ${ }^{30} \mathrm{We}$ are meant to read lines like these and ask ourselves: "How is it possible to live in the 1990s and think in terms as patently ridiculous as these?' And since we cannot possibly conceive of the world in this kind of absolutist way, which was, of course, all that Marxism was ever capable of articulating, then we must abandon this language and this project and opt for another kind of politics, one more attuned to less categorical thought, one less totalizing and more discursive.

As we find our way to this end we are being moved ideologically. The epoch strikes back.

26 Ellen Meiksins Wood, The Pristine Culture of Capitalism: An Historical Essay on Old Regimes and Modern States (London 1991), 93.

27 Among many exemplary texts that could be cited see Peter Dews, Logics of Disintegration: Post-structuralist Thought and the Claims of Critical Theory (London 1987); Norman Geras, Discourses of Extremeity: Radical Ethics \& Post-Marxist Extravagances (London 1990); Kate Soper, Troubled Pleasures: Writings on Politics, Gender and Hedonism (London 1990).

28 As one example see Bryan D. Palmer, Descent into Discourse: The Reification of Language and the Writing of Social History (Philadelphia 1990), 48-86.

29 Geras, Discourses of Extremity, 73.

30 Ernesto Laclau and Chantal Mouffe, Hegemony and Socialist Strategy: Towards a Radical Democratic Politics (London 1985), 2. 


\section{Looking Backward}

It is small comfort, but comfort nonetheless, to know that this has happened before. The ideology of postmodernism, whose identity is wrapped up in its refusals of all connection to the past, is, in many important ways, a set of interpretive reincarnations and continuities locatable in the ebb and flow of class struggle. The best of the poststructuralists (who, ironically enough, often refuse to be identified as such) know this intuitively. Derrida has proclaimed with confidence: "we can pronounce not a single destructive proposition which has not already had to slip into the form, the logic, and the implicit postulations of precisely what it seeks to contest." ${ }^{\text {"31 }}$

Marx's and Engels' polemics of the 1840s, for instance, gave rise to the birth of ideology as a conceptualization of the socially-constructed nature of knowledge, in the process challenging and undermining the hegemony of Hegelian philosophy. ${ }^{32}$ In their intellectual crossing of swords with Feuerbach, the German "true socialists" and Proudhon, Marx and Engels pilloried the systematic philosophical denigration of materialist explanatory powers and railed against the idealism that ordered historical development along lines of spiritual conceptions and platonic categories. Marx was at pains to reclaim language, not as abstracted from and prior to profane humane activity, but as the very expression and product of "actual life," most emphatically those aspects of generating sustenance and, in the process, making history. ${ }^{33}$ Throughout this debate, philosophical idealists such as the "true socialists" expressed, according to Marx, shocked indignation of crude antitheses and retreated into "kaleidoscopic" imagery and symbolism, a methodological imperative that revelled in "infinite multiplicity."34 Writing to Annenkov at the end of 1846, Marx summed up his views of Proudhon's recently-published The Philosophy of Poverty, from which the "true socialists" borrowed ideas on property. Eternal ideas and cateogries of pure reason were, in the discourse of the 1840 s, thus constantly being counterposed to and elevated above human beings and their practical life. This dualism seemed to Marx to be recurring in many forms, understating "the profane origin and...history of...categories" that were being ideologically deified ${ }^{35} \operatorname{In}$ Ludwig Feuerbach, Engels expressed contempt for those 1840s radicals who lost themselves in "disgusting literary phrasemaking and suffocating sentimentality," forcing the communist agenda away from proletarian revolution and the transformation of productive life and toward "the liberation of mankind through 'love'." 36 Thus, as Ellen Wood points out, when Marx and Engels came to write the Communist Manifesto, they struck hard at the ideology of their times and epoch. Radicals were enjoined, at the historic moment of class formation and struggle associated with consolidating industrial capitalism, to abandon materialism and a corresponding politics because socialism had "ceased to express the struggle of one class against another." The "true socialists" who promoted this 'vision' "felt conscious of...representing, not true requirements, but the require-

31 Derrida, "Structure, Sign, and Play," 280-81.

32 For one reading of this see Harold Mah, The End of Philosophy, the Origin of 'Ideology': Karl Marx and the Crisis of the Young Hegelians (Berkeley 1987).

33 Marx and Engels, German Ideology, esp. 19, 28-29; Gerard Bekerman, Marx and Engels: A Conceptual Concordance (Oxford 1981), 93

34 Marx and Engels, German Ideology, 85, 109.

35 See Marx and Engels, Selected Correspondence, 1846-1895: A Selection with Commentary and Notes (New York 1935), 5-18.

36 Frederick Engels, "Ludwig Feuerbach and the End of Classical German Philosophy," in Karl Marx and Frederick Engels, Selected Works (Moscow 1968), 603. 
ments of Truth; not the interests of the proletariat, but the interests of Human Nature, of Man in general, who belongs to no class, has no reality, who exists only in the misty realm of philosophical fantasy." 37

Generations of Marxists subsequent to the founders of historical materialism grappled with various ideological challenges. But up to the momentous and fragmenting events of World War I, which saw the making of the first workers state and acute splits in the socialist organizations spawned by Marx and Engels, the Marxist project was one of extending, rather than transcending, the work of its original architects. Writings on philosophy and economics continued the work of Marx and Engels, and were avidly read by workers eager to grasp the fundamentals of socialism. ${ }^{38}$

From the 1920s on, however, as Perry Anderson has shown, so-called 'Western Marxism' developed in a series of formal shifts and thematic innovations. The material context was hardly propitious, bounded as it was by capital's expansive economic and ideological authority, the on-going degeneration of a now thoroughly Stalinized 'socialism', and a series of historic defeats of the workers movement. 'Western Marxism' increasingly took on the trappings of a Discourse on Method, divorcing itself from the aims of Marx and Engels in a textual immersion that returned the philosophy of the workers movement to Philosophy; whereas Marx and Engels settled their score with Hegel and then moved increasingly in the post-1850 years into political economy, the Marxism of the post-1920 Third International, in which Lukacs and, for a time, Korsch, figured prominently, revitalized Hegel and, in the process, reinserted Marxism into a language and stance drawn inevitably closer to the reification of categories and idealist constructions Marxism had its very beginnings in opposing. Even where Marxist thought was more consciously crafted out of concern with the political and the economic, as in the writings of Gramsci, the defeats of the revolutionary left forced theory into specific cul-de-sacs: Gramsci's prison writings, among the most important body of Marxist theory to be produced in the post-1920 years, developed within the confines of incarceration. Cornered as he was by the harsh defeat of class struggle, Gramsci wrote in codes and cryptic passages. His counterparts, more physically 'free', but limited by the same political setbacks, their obeisance or banishment from Stalinism's good graces, and their distance from a vibrant and combative workers movement, produced Marxist theory no more accessible to a mass working-class audience. In this they differed greatly from both Marx and Engels, whose care to write in ways that would reach the emerging nineteenth-century proletariat was well known, as well as from later generations of revolutionaries who, like Lenin, Trotsky, and Luxemburg, produced sustained analyses of capitalism's historical development as well as materialist explorations of major political events and polemics on tactics and strategic direction. As Anderson concludes, Marxist "theory became, for a whole historical period, an esoteric discipline whose highly technical idiom measured its distance from politics." Like Gramsci himself, "the language of Western Marxism... was subject to a...historical censor: the gulf for nearly fifty years between socialist thought and the soil of popular revolution." 39

In the inter-war years and beyond, then, Marxist theory, subject to a series of materialist pressures, was transformed. It was returned, ironically enough, to its

37 Quoted in Wood, The Retreat from Class, 1.

38 For the United States, for instance, see Paul Buhle, Marxism in the United States: Remapping the History of the American Left (London 1991).

39 Perry Anderson, Considerations on Western Marxism (London 1976), quotes from 53, 55. 
beginnings, but in ways that perhaps stood those origins on their head. ${ }^{40}$ And in the process the tracks of historical materialism were laid in specific ways that increasingly obscured this process, moving Marxist theory consciously away from an appreciation of the intent of the texts of the 1840s, nudging it in directions that reclaimed for Philosophy itself pride of place within the Marxist project, questioning, sometimes implicitly, sometimes explicitly, the place of a resolutely historical materialism. ${ }^{41}$ Like much 'critical' theory, Marxism was thus not immune from the general trend that Allan Megill has denoted aestheticism, an "enclosure within a self-contained realm of aesthetic objects and sensations, and hence...a separation from the 'real world' of nonaesthetic objects...a tendency to see 'art' or 'language' or 'discourse' or 'text' as constituting the primary realm of human experience."42

It is this development of Western Marxism, its aestheticism and its increasing gravitation to the text and its interrogation, that prepared the way for what might metaphorically be described as an Althusserian coup and, from within the ranks of historical materialism, a counter-strike. That counter-strike culminated in Thompson's "The Poverty of Theory," a sustained essay that was of course not a repudiation of theory, but a refusal of a particular project of a specific kind of theory. What Thompson literally could not stomach was the extent to which Althusserian Marxism appeared to be "a self-generating conceptual universe which imposes its own ideality upon the phenomena of material and social existence, rather than engaging in a dialogue with these.... The category has attained to a primacy over its material referent; the conceptual structure hangs above and dominates social being." Althusser generated such Thompsonian scorn because, "He knows that Theory could write better history. $" 43$

Thompson's polemic reaches back to the original Marxist discontents with the Hegelianism of the 1840s. It gathers force in the context of a Western Marxism drawn increasingly into the field-of-force of aestheticism, an ordering theoretical imperative that, by the time of Althusser, threatened to suppress both components of historical materialism with the weight of conceptual absolutism and idealism. Whatever the problems of the Thompsonian counterstrike - which included the canonization of "historical' practice as discipline - "The Poverty of Theory," as Perry Anderson has noted, "turned an intellectual page - irreversibly. Whatever our view of the merits of the dispute, it is henceforward impossible for Marxists to proceed - as they did for many years, on either side - as if their history and their theory were two separate mental worlds, with little more than occasional tourism, mildly curious, between them." "Theory now is history," Anderson concluded, "with a seriousness and severity it never was in the past; as history is equally theory, in all its exigency, in a way that it typically evaded before." ${ }^{44}$

40 For comment see Douglas Kellner, Critical Theory, Marxism, and Modernity (Baltimore 1989); Eugene Lunn, Marxism and Modernism: An Historical Study of Lukacs, Brecht, Benjamin, and Adorno (Berkeley 1982).

41 For a sequel to Anderson's Considerations on Western Marxism of relevance here see Perry Anderson, In the Tracks of Historical Materialism (Chicago 1984).

42 Allan Megill, Prophets of Extremity: Nietzsche, Heidegger, Foucault, Derrida (Berkeley 1985).

43 Thompson, "Poverty of Theory," 205, 223.

44 Anderson, In the Tracks of Historical Materialism, 26. Thompson's "Poverty of Theory" gave rise to a massive literature of response, much of it hostile. See, for some typical statements: Paul Q. Hirst, Marxism and Historical Writing (London 1985), 57-90; Anthony Easthope, British Poststructuralism since 1968 (London 1988), 96-105; and the commentaries in Raphael Sarnuel, ed., People's History and Socialist Theory (London 1981), 375-409. 
Anderson's statement had the unfortunate ring of a truth that, as soon as it was uttered, fell victim to the immense ideological carnage of a world in which Marxism as both a practical possibility and a theoretical edifice was constantly assailed. Part of the 1982 Wellek Library Lectures at the University of California, Irvine, Anderson's comment appeared as the political economies of Eastern Europe exposed the vulnerability of Stalinism; within a decade the world of actually existing socialism no longer existed. Along the way Marxism lost much of its staying power, never all that strong, among the Western intelligentsia, and theory imploded in the poststructuralist free-fall, in which subjectivity, discursiveness, and an intense questioning of what is 'real' threatened to displace not only the analytic categories of historical materialism, but the very suggestion that history itself could possibly contain meaning. "The Poverty of Theory" was thus rather curtly dismissed in most poststructuralist circles as either an attempt "to keep the disciplines going," or, worse, as the Marxist mask of essentially bourgeois thought, as an ideological illusion pacifying "the exploited through story telling passed off as critical thought."45 Statements such as these continue to convey precisely the view of Marxist historical practice muddling around in the quirkiness of the past, innocent of the method of actual theoretical science as true knowledge - that Thompson found so dangerous in Althusserian structuralism. In their critique of 'history', which universally proceeds without attending to the construction of another theoretically-acceptable account of the past, they come perilously close to denying the possibility of actually producing texts of historical materialism.

\section{In Defence of Marxist Historiography}

It is necessary to offer another view, and bluntly so. First, neither structuralism nor poststructuralism, as Theory, have produced actual histories of substance and sensitivity. Whatever the merits of the Richard Johnson-led Centre for Contemporary Cultural Studies forays into making histories, the fundamental gulf dividing this collective project of historiographic critique and the actual histories produced out of the insights of such critical readings is both wide and obvious. ${ }^{46}$ Second, in the absence of 'Theory writing better history', it is important to restate the fundamental contribution of the English Marxist historians - especially the 1950s, 1960s, and 1970s writings of Hill, Hobsbawm, Hilton, and Thompson - and to point to the impact of historical materialism in generating reconsiderations of such central matters as the transition from feudalism to capitalism. ${ }^{47}$ Far from refusing theory, this historical writing is poised at the fruitful conjuncture of conceptualization and empirical explorations of the admittedly problematic evidence generated out of the past, a practice that demands the integration of structure and agency, being and consciousness, past and present, subject and interpretation, and the self-reflective elaboration of the relationships among these linked processes.

45 See Gayatri Chakravorty Spivak, In Other Worlds: Essays in Cultural Politics (New York 1988), 284; Sande Cohen, Historical Culture: On The Recoding of an Academic Discipline (Berkeley 1986), 228-229.

46 See, for instance, John Clarke, Chas Critcher, and Richard Johnson, ed., Working-Class Culture; Studies in history and theory (London 1979); Richard Johnson, et al., ed., Making Histories: Studies in history-writing and politics (London 1982).

47 For a brief introduction to the English Marxists see Harvey J. Kaye, The British Marxist Historians: An Introductory Analysis (Cambridge 1984); and for specific comment on American Marxist historiography, Anderson, In the Tracks of Historical Materialism. 
There was a time when these histories were recognized as contributions to historiography and theory, as one proof of historical materialism's richness. Over the course of the 1980s, however, that contribution and richness have been repeatedly questioned. Poststructuralism as ideology in the guise of theory has been persistent in its challenge to Marxist historiography, but precisely because it rarely deals with actual historical texts, preferring instead a theoretical gloss on what theorists have said of history, or rather glib characterizations of specific historiographic traditions, entirely in line with its own penchant for conceptual absolutism, this has not proven a particularly destructive critique. More destabilizing have been those who have chosen to jump the ship of historical materialism. For if poststructuralist theorists have exhibited markedly little actual engagement with either the content of the past or its interpretation by practicing historians, there have been those within the range of historical materialism's practice who have gravitated toward the determinations of discourse and representation and, in the process, struck specific blows at the validity of Marxist historiography.

It is virtually mandatory to begin the dissection of this process with Gareth Stedman Jones's reconsideration of Chartism and his brief introductory remarks to the collection of essays, Languages of class, which gave that article an appropriate home..$^{48} \mathrm{I}$ will indeed commence with this text, but in doing so suggest that it has achieved the status of an unwarranted, albeit negative, canon: undertheorized, ahistorical in its decontextualization of Chartism, and rather old-fashioned in its reduction of discourse to the published accounts of the labour press (a kind of nostalgic return to the syllabus of 'Political Thought', as Dorothy Thompson has noted), "Rethinking Chartism" and the injunctions of the Stedman Jones introduction have achieved a certain notoriety precisely because they signalled the acceptability of a retreat from historical materialism premised not on the reasoned labours of theory and research, but on assertion congruent with the ideology of the times.

Stedman Jones laid great stress on the ways in which a language of eighteenthcentury radicalism overdetermined the struggles of the 1830 s and 1840 s to the point that they were less about what materialist histories said they meant, class conflict embedded in the socio-economic transformations associated with the Industrial Revolution, and more about the continuity in populist discontent with the state, expressed in a particular discourse. This was an insightful, but extremely limited, reading of Chartist rhetoric; it by no means established the autonomy of language and its overshadowing of class experience asserted aggressively by Stedman Jones. As literally a score of materialist critiques of "Rethinking Chartism" establish, the history of English class relations and conflicts in the third quarter of the nineteenth century is not one in which class formation and language, economics and politics, mobilization and program, challenge and cultural continuity can be so neatly categorized and dichotomized. ${ }^{49}$

48 See Gareth Stedman Jones, Languages of class: Studies in English working class history, 1832-1982 (Cambridge 1983), esp. 1-24, 90-178.

49 The literature on Stedman Jones's essay, much of it cast in materialist opposition, is now considerable. See, for instance, Palmer, Descent into Discourse, 128-133; Wood, Retreat from Class, 102-115; John Foster, "The Declassing of Language," New Lefi Review, 150 (March-April 1985), 29-46; Paul A. Pickering, "Class without Words: Symbolic Communication in the Chartist Movement," Past \& Present, 112 (August 1986), 144-162; Joan Scott, "On Language, Gender, and Working-Class History," International Labor and Working Class History, 31 (Spring 1987), and the responses to Scott by Palmer, Stansell, and Rabinbach, 1-36; Dorothy Thompson, "The Languages of Class," Bulletin of the Society for the Study of Social History, 52 (No. 1, 1987), 54-57; Neville Kirk, "In Defence of Class: A Critique of Recent Revisionist Writing on the Nineteenth-Century Working 
The Stedman Jones essay thus introduces us to the ways in which historical materialism has been undermined from within its own ranks. But in this introduction two points must be made, before moving on to consider a more substantive statement on the reconsideration of class as it is made materially and historically.

First, Stedman Jones's article, with its revisionist tilt away from the traditional orthodox materialist reading of Chartist experience, registered such a profound impact among social historians precisely because it came from an author long recognized as a Marxist historian with an acute sense of theory. But what was missed within an appreciation of Stedman Jones's Marxist credentials was the extent to which his Marxist theory had long been a captive of the aestheticism of 'Western Marxism', a process of political and intellectual formation that moved Stedman Iones easily in the direction of poststructuralism's ideological framing of ideology. Signs of this could be seen, not only in Stedman Jones's explicit theoretical statements, but also in his more resolutely historical examination of class relations in Victorian society ${ }^{50}$ By the time of the writing of the Chartist essay, this trajectory had run its course in a series of blunt statements that demanded nothing less than a reconsideration, not so much of Chartism, but of Marxist method and theory. Insisting implicitly on a transhistorical conception of class consciousness as the programmatic direction of 'a class for itself', "Rethinking Chartism" proclaims the non-existence of this program in the published statements of the labour press of the 1830s and 1840s. Stedman Jones was now convinced of "the impossibility of abstracting experience from the language which structures its articulation." His aestheticism was voiced in his insistence that it was the terms and propositions within language that demanded systematic exploration, rather than "a putative experiential reality of which they were assumed to be the expression." On this "contemporary intellectual terrain," claimed Stedman Jones, history must renew itself. And this renewal, of course, was to stand in opposition to "economic determinism" and "mechanical Marxism," and to proceed on the basis of the "broader significance" of post-Saussurian linguistic analysis and its implicit critique of any assumed causal relationship between being and consciousness. ${ }^{51}$ As the materialist response to Stedman Jones pointed out with some regularity, this embrace of Saussure and the resulting linguistic turn were made abruptly and with little in the way of developed theoretical elaboration or justification.

"Deconstructing" Stedman Jones, however, suggests the possibility of reading his revisionism in interesting ways. For there lies between the lines of "Rethinking Chartism," not unlike a Derridean 'trace', the high structuralism of the Stedman Jones of the 1960s and 1970s: ordering each layer of the argument advanced is an idealized understanding of class consciousness that the actual socio-economic and historical relations of the Chartist moment insured would never become a practical and mass

Class," International Review of Social History, 32 (1987), 2-47; Robert Gray, "The Deconstructing of the English Working Class," Social History, 11 (October 1986), 363-373; James Epstein, "Rethinking the Categories of Working Class History," Labour/Le Travail, 18 (Fall 1986), 195-208; Epstein, "Understanding the Cap of Liberty: Symbolic Practice and Social Conflict in Early Nineteenth-Century England," Past \& Present, 122 (February 1989), 75-118; Nicholas Rogers, "Chartism and Class Struggle," Labour/Le Travail, 19 (Spring 1987), 143-152; Christopher Clark, "Politics, Language and Class," Radical History Review, 34 (1986), 78-86.

50 See Gareth Stedman Jones, "History: The Poverty of Empiricism," in Robin Blackburn, ed., Ideology in Social Science: Readings in Critical Social Theory (New York 1973), 96-115; "The Marxism of the Early Lukacs," in New Left Review, ed., Western Marxism: A Critical Reader (London 1978), 11-60; Outcast London: A Study in the Relationship Between Classes in Victorian Society (Oxford 1971).

51 Stedman Jones, Languages of class, esp. 13, 20-21, 24. 
possibility. It is understandable that given the continuing, if deteriorating, hold of merchant capital, outwork, and sweated metropolitan and country forms of petty production, many segments of the labouring poor would see their plight not in terms of a Marxist grasp of the way surplus value was extracted from them, and therefore of the need for a new proletarian order whose origins inevitably lay not in challenging government corruption but in overturning the state as a central foundation of capitalist power, but as the inadequacy of the price their product commanded and the place of a parasitic political caste in perpetuating such a political economy of inequality. An historical analysis of the economic context, acknowledging national patterns and local divergences, might well suggest, ironically, the lack of materialist justification for insisting that an incompletely formed working class speak in the words and meaning of a Marxist kind of class consciousness that was not quite yet firmly placed on the contextualized agenda of class struggle. This does not mean, of course, as Stedman Jones claims, that language determines political being, but that material life sets the boundaries within which language and politics develop. Nor does it understate the importance of the state, which must be granted its relative autonomy at the same time as it is located in relation to the development of the economy. But this is not the lesson that Stedman Jones's revisionism draws out of the experience of Chartism. Instead, he stands simultaneously the ground of denial of Peter and the terrain of dichotomization of Solomon: "Attention to the language of Chartism suggests that its rise and fall is to be related in the first instance not to movements in the economy, divisions in the movement, or an immature class consciousness, but to the changing character and policies of the state - the principal enemy upon whose actions radicals had always found that their credibility depended., 52

What such a conclusion suggests is that class is immaterial where a fully-elaborated class consciousness cannot be unambiguously located. The elevation of the state to the status of prime determinant, as opposed to the exploitative and oppressive relations of a class order that conditions a particular kind of state apparatus and practice, thus moves Stedman Jones into a particular politics of resistance. Or, perhaps, it is the other way around: a political reading of the contemporary moment may well be conditioning a specific interpretation of Chartism's meaning. For the second point that needs to be made in regarding Stedman Jones as an introduction to the current displacement of historical materialism is more crudely political. In response to the many replies to the "Rethinking Chartism" essay, all of which call for more theoretical clarity, Stedman Jones has offered not a single line of elaboration. Rather, it would seem that the justification for Stedman Jones of the retreat from historical materialism and class as one of its major conceptual foundations is the politics of the moment. Against Thatcherism, he proposed taking the Labour Party out of its antiquated class politics and forging a genuine popular front of all progressives:

If the Labour Party is ever to reverse its present involution, it will have to rethink the social alliances upon which it could be based in terms of what they now potentially share in common. At the moment, the emergence of new and potentially unifying strategies is thwarted by an enduring major premiss of Labour Party thinking: the perception of one part of its constituency as a homogeneous proletarian estate whose sectional political interest is encompassed by trade unions, and of the other part as a heteroclite aggregate of idealists, notables or entrists to be humoured, promoted or circumvented.... It is this premiss, still embodied in the structure and constitution of

52 Stedman Jones, Languages of class, 178. 
the Labour Party, which inhibits a believable appeal to today's real poor or oppressed (immigrants, women, the unemployed)...Labour will not be able to construct a socialist politics that addresses this situation as long as its inherited thinking and practices continue to be deformed by the largely unquestioned acceptance of an anachronistic and now disastrous social distinction between mental and manual labour..$^{53}$

Against the 'crisis of communism', Stedman Jones proposes the failure of the political language of "marxism-leninism," now at "the end of the road, both in word and deed." 54 It is hard to read political writings such as these and not be struck with the extent that being does determine consciousness, that in a political moment of profoundly anti-Marxist tenor, the conscious identification with Marxism fades and falters within a layer of intellectuals who see little to be gained from staying with a ship that fashion and fatalism have seemingly sunk.

The assumptions and direction of Stedman Jones have recently been developed in a more sustained effort to comment on industrial England and the question of class in the period 1840-1914. Patrick Joyce's recently-published Visions of the People is a lengthy essay that oscillates between historiographic critique and synthetic statement. Drawing far less on original research than on Joyce's reading of journal literature and published monographs, the text ranges across the cultural landscape of nineteenth-century England, exploring the moral and organizational discourses of labour, the significant place of custom, symbolism, and language (as dialect and sense of the past), and the ways in which mass entertainment - centred in the music hall, the broadside ballad, and the popular theatre - orchestrated specific understandings of collective experience. Much of what Joyce has to say is welcome and useful. What is at issue here is his insistence that the history of these years constantly returns to repudiations of class and, in place of this seemingly simple economistic and conflictual identity, the presence of a populist sense of 'them' and 'us' that is both more discursive and less constricting than the usual Marxist-imposed conceptual edifice.

At the foundation of this historical materialist project Joyce finds nothing less than "the tarnished idol of class." What Joyce means by this, like Stedman Jones, is actually not class as a structural relationship to the means of production, a relationship into which men and women are born and, with time, enter into through their subsistence activities, but rather class consciousness. Visions of the People turns on a ubiquitous insistence that "the consciousness of a class and the consciousness of class" are not always the same thing, as if any Marxist ever said they were. The language of labour just "did not add up to 'class consciousness'." Because the English proletariat did not embrace a language of unadulterated class consciousness, a dialect of Marxism, Joyce wants to move historians away from class: "The notion of 'languages of class' carries great dangers."' But in as much as there is a constant refrain throughout the period of industrial-capitalist consolidation of class difference, Joyce cannot quite bring himself to jettison the term class. Instead, he undercuts it on virtually every page, only to bring it in as a kind of obscured image, conceptually overshadowed by the somehow more robust rhetoric of populism: "Rich and poor, the people and the ruling class, were the dominant elements, rather than considerations of class." In this curious sentence the problematic fence-sitting and conceptual overdrive of the Joyce volume are summed up in two lines: a language of populism

53 Stedman Jones, "Why is the Labour Party in a Mess?" in Languages of class, 256.

54 Gareth Stedman Jones, "The Crisis of Communism," in Stuart Hall and Martin Jacques, ed., New Times: The Changing Face of Politics in the 1990s (London: 1989), 230-236. 
overrides not only instances of class consciousness, but class as a structural relation to production; and it does so in ways as tyrannically totalizing and 'essentialist' as those now uniformly associated with the use of the concept of class. Populism is such a useful interpretive container because anything can be poured into it, while so much else can be shut out by arbitrary adjustment of the lid. This kind of analytic latitude proves particularly useful to an account that cannot escape class even as it is immersing the reader in a narrative of denial. How is it possible for an historian such as Joyce to speak of 'the ruling class' and yet insist that 'considerations of class' were subdued? ${ }^{55}$

Without seeming to know it, Joyce has offered a fascinating exploration of the multi-faceted construction of an ideology obscuring class all the more effectively because it resonates with class divisions, accepts the inevitable recognition of class difference, but masks the actualities of class power, commenting on how this ideology was also internalized and propogated by the working class itself. Joyce then confirms this ideology as 'real', taking the failure of the working class to identify the economic bedrock of class relations and consciousness as proof that notions of station, nation, and honour were somehow separate and dichotomized from class and more resilient as sources of identification. Small wonder that Joyce introduces his book with the statement that, "The vested interest workers and employers have in co-operation is at least as great as any tendency toward conflict," or that he insists that, "The stuff of class was the stuff of deference." ${ }^{.56}$ Inspired by the recent work of William Reddy, who has been at pains to banish class from the vocabulary of historical scholarship, Joyce paints the experience of workplace tension as driven by superstructural engines somehow severed from the base of crude economic relations: "industrial conflicts were about mastership and authority, respect and honour, as much as they were about material considerations." With labour's values and language cast in conceptions of justice and honest remuneration, Joyce expresses the view that "little or no sense of labour and capital as the basic social dichotomies" existed in Victorian England, where "moral and not economic realms" were looked to by the people as decisive, insuring that "an explicitly class vocabulary is notable by its absence."

Typical of most poststructuralist histories that retreat from class, Visions of the People commences with an assertive, unquestioning embrace of the ideology of postmodernism, replete with the mandatory dismissals and caricatures: there is no need to "retain the fig-leaf of Marxist decencies"; and the supposedly Marxist preoccupation with "'struggle' as the defining mark of class," is jettisoned (no matter that this is not universally the point of departure in a Marxist appreciation of class origins, but rather the inevitable outcome of social relations ordered by the logic of exploitation, accumulation, and alienation). Joyce commences with the blunt statement that received wisdom (Marxist?) "has in fact become a dead weight," and in joining the ranks of those attacking the inappropriate and inadequate concept of class

55 Patrick Joyce, Visions of the People: Industrial England and the question of class, 1840-1914 (Cambridge 1991), esp. 97, 113, 254.

56 Joyce, Visions of the People, 3, 133. It is not that deference and the ideology of labour-capital harmony need be denied by historians, only that they need be situated, contextualized, and explored, rather than reified. This was more successfully scrutinized in Joyce's earlier work, although there is no mistaking the connection between that text and his current concerns. See Patrick Joyce, Work, Society, \& Politics: The Culture of the Factory in Later Victorian Britain (New Brunswick, New Jersey 1980).

57 Joyce, Visions of the People, 110, 246. The laudatory assessment of William M. Reddy, Money \& Liberty in Modern Europe: A Critique of Historical Understanding (Cambridge 1987), is counterposed to the discussion in Palmer, Descent into Discourse, 134-144. 
he has produced a book that is "at least in part...a product of its post-structuralist times." Not conflict and class, but "extra-proletarian identifications such as those of 'people' and 'nation' are involved...notions combining social justice and social reconciliation." "The accent on social concord and human fellowship is very strong," concludes Joyce, in an echo of the German true socialism of the 1840s that we have already encountered. Joyce's poststructuralism is thus simultaneously ideological and undertheorized. Deconstruction means little more than acknowledgement of the proliferating identities of people, poststructuralism a 'theoretical' gesture to the determinations of language. And with this kind of substantive skirting of the conceptual foundations of his study, Joyce is able to lapse into the very problematic oppositions that his own proclaimed 'theory' would question. Class consciousness is cast in oppositional ultimatism to class; economy and morality are dichotomized; populism, as an expansive politics of rhetoric and identity, replaces the more rigidly closed Marxist understanding of class, which has contained both too much and too little. Joyce concedes that populism as such an all-embracing interpretive concept is "too baggy but that it is a necessary and useful heuristic device" (unlike, apparently, class).$^{58}$

The result is a book that tells us a great deal, mystifies those findings unnecessarily, and loses its moorings in a tendency to scrutinize class for evidence of fully-forged class consciousness at the same time that populism is recognized to clasp a part of class (in differential social structural terms that translate into values and world views as likely to be fatalistic as conflictual) within its reach while closing its fist against expressions of anything approximating its conscious realization. What could have been an important statement about the making of class as a presence in an English society characterized by the partial and problematic non-making of class consciousness withdraws into textual and analytic waffling in which class is acknowledged at the same time as it is displaced in the accentuation of rhetoric and representation, which hover above material structures of power, authority, and dominance. As befits a historian obviously adrift in the complex maze of ideology and structure, consciousness and being, Joyce offers up a grand statement nullifying class that can nevertheless only conclude on a note of postured balance: "Class continued to be only one of the many ways in which the social order was envisaged, though in the integrity of the self-created traditions of the nineteenth-century labouring poor one can unmistakably detect more than the semblance of a class talking, if not of class talk." 59

Much historical writing influenced by poststructuralist thought thus assimilates a kind of instinctual anti-Marxism that, not surprisingly, understates class in a perfunctory defiance of 'economism' that results in little more than a reified representationalism. Stedman Jones and Joyce can well stand as surrogates for two distinct paths converging, in the 1980s and 1990s, on this intellectual end.

The first path is travelled by those Marxists once sympathetic to structuralist critiques of so-called Thompsonian socialist-humanist historiography. Evident in the case of Stedman Jones, this trajectory can also be discerned in the movement of other historians away from the classificatory scolasticism of the 1970s, usually associated with one or another European Marxist 'theorist', toward the new-found explanatory power of language, discourse, subjectivity, and identity, little of which is acknowledged to be embedded in material relations. Ironically enough, historians who have walked this path of analytic development often commenced their journey decidedly

58 Joyce, Visions of the People, 1, 3, 5, 11-12.

59 Joyce, Visions of the People, 342. 
hostile to 'culturalism', but now find themselves standing the terrain of culture far more self-assuredly and uncritically than did Thompson or his supposed followers.

In the case of Canada I would situate Ian McKay directly in this 'evolutionary' space, albeit acknowledging his peculiar capacity to indulge his taste to be all things to all people. McKay early jumped on the anti-culturalist bandwagon, paying homage to the wisdom of Stedman Jones and ending a long-winded discussion of the concept of culture with the confident statement: "We close the logical and political circles only by a return to the concrete: to the determinate abstractions of Capital and to a logical political practice." Culture, Mckay insisted, "merely designates a central but empty place where the theories of historical materialism should be." Ten years later, the intellectual-political climate decidedly different, McKay's publications are of a different order. One recently-released text, a reader on post-Confederation Canada that complements its predecessor companion volume's political narrative "by focussing on the social and on the cultural," ordering readings in these areas around the concepts liberalism, hegemony, and gender, concludes with yet another powerfully assertive injunction: "To explore ourselves through probing the construction of our modernity is the daunting and fascinating challenge of Canadian history." McKay is thus seldom at a loss for words to tell us what to do. Beyond this continuity in the form of his presentation, however, lie significant shifts. For if McKay has not abandoned class and rejected historical materialism, there is no denying the extent to which his analytic framework has changed; there is a world of difference separating the logic of Capital and that of 'our' modernity, an experience of seemingly overriding importance. A recent McKay review addressing the national question concludes: "The redefinition of 'Canada' surely means that the marxist version of 'Canadian working-class history' is being overtaken by events...Canadian historians...face a...severe, agonizing and troubling task in facing a future which appears likely to be post-modern, and, it appears, quite possible, post-Canadian as well." There may be many reasons to revise our historical interpretation of class experience, but it is surely questionable to undertake that revision solely on the basis of contemporary postmodernity, the interpretation of which remains an open rather than a closed question, and the outcome of which is necessarily uncertain. Yet, like Stedman Jones, whom I have argued interprets Chartism in light of his own reading of the failures of the Labour Party during Thatcherism, McKay's historical relativism, conditioned by the supposed current break-up of Canada, drifts dangerously in the direction of presentism. In his introduction to the reader in post-Confederation Canadian history which he edited, McKay adopts an eminently postmodernist justification for his presentism: "The past no longer exists; and history, which is how modern western societies try to understand and to 'master' the past is an intellectual activity undertaken in the present." Of course, one wants to say, but... This would all be less galling if McKay's most current publication, a co-authored preface to a collection of journalistic articles drawn from the populist voice of east coast regionalism, New Maritimes, did not stake out certain political/intellectual ground. To the question, "What does the future hold for New Maritimes, McKay and his co-editor, Scott Milsom, offer a rather curious scenario: "One fashionable vision would have us decline gracefully into the twilight of a contented middle age, regarding our youthful socialism with an indulgent smile, sipping white wine by our Jacuzzi. Chastened by the 'fall of communism' and mellowed by our own modest little success, we could spend our twilight years writing obscure articles about postmodernism and about the 'end of history' in this most liberal and happy of decades." To 
those familiar with McKay's pronouncements, the editors' unambiguous rejoinder to this depiction of their project, a blunt "Fat chance," may come as something of a surprise. Yet this is just the kind of 'have it all ways' relationship to postmodernism - for it in texts emanating from the centre, against it when appealing to the folks down home - that one would expect from a tradition that commenced as high anti-culturalism, redefined the 'cultural' and sidestepped the political, and moved on to presentist, pluralist relativism, a space now occupied by both Gareth Stedman Jones and Ian McKay, neither of whom seems much interested in interrogating the shifting ground of their own changing positions. ${ }^{60}$

The second path, of which Joyce is a prime example, encompasses those historians who were never all that much at home within Marxist analysis, and who have found in the celebration of discursive identities a theoretical rationale for their uncomfortableness with class not available to them as little as ten years ago. This process culminates in a loosening of the materialist moorings which bound fruitfully most social history of the 1970 s. Joyce's first book, for instance, was a sustained critical engagement with the notion of the labour aristocracy, a term that Marxist historians developed through studies that advanced our understanding of class experience conceptually and empirically. With Visions of the People, however, this need to relate to a particular historiography is quietly deflated: "the labour aristocrat so beloved of recent historiography was rather more a rhetorical than an economic construct." When entire layers of working-class life can be reduced to the rhetorical, social history enters a particular kind of free-fall, propelled, quite often, by the ideological whirlwind of postmodernity.

This is evident in what is perhaps the most sustained and serious historiographic breakthrough of the last two decades. Feminist history, pivoting on gender relations (and admittedly highly variegated,) is simultaneously Marxism's most serious challenge and social history's greatest advance. Not surprisingly, it registers its most profound impact in terms of our understanding of class. Nowhere in the historiography, moreover, has poststructuralist thought made comparable inroads, and postmodernist feminist theory and historical writing is now metaphorically cross-referenced. ${ }^{62}$

As in the case of Stedman Jones, Joan Wallach Scott has attained a particular stature as central to the making of a new, poststructuralist feminist historiography. Unlike Stedman Jones, Scott never embraced the theoretical aestheticism of Western Marxism, opting instead for a pragmatic radical engagement with the terrain of American politics. In her formative years as an historian this translated into a robust, if occasionally naive, attachment to Thompson's Making of the English Working Class. But as the possibilities of class politics appeared to fade in the 1980s, Scott turned her back on workers as historical subjects and offered a series of curt and cavalier dismissals of Marxism. She moved decidedly to women as subjects and insisted increasingly on the importance of gender as the central category of social history. While her earlier historical writing had been fairly traditional in its subdued

60 Ian McKay, "Historians, Anthropology, and the Concept of Culture," Labour/Le Travail, 8/9 (Spring 1981-82), esp. 228; McKay, ed., The Challenge of Modemity: A Reader on Post-Confederation Canada (Toronto 1992), esp. xxiv; McKay, "Unidentified National Objects," Labour/Le Travail, 28 (Fall 1991), esp. 294; Ian McKay and Scott Milsom, ed., Toward a New Maritimes: A Selection from Ten Years of New Maritimes (Charlottetown, Prince Edward Island 1992), 10.

61 Joyce, Work, Society \& Politics; Visions of the People, 57.

62 For a brief introduction see Palmer, "The Eclipse of Materialism: Marxism and the Writing of Social History in the 1980s," in Ralph Miliband, Leo Panitch, and John Saville, ed., Socialist Register, 1990 : The Retreat of the Intellectuals (London 1990), 126-137. 
espousal of theory, by the later 1980s Scott was unambiguously poststructuralist, perhaps the most ardent proponent of a deconstructive, Foucauldian feminist historiography outside of France. When her collection of essays, Gender and the Politics of History appeared in 1988 it was hailed by Lynn Hunt, author of a poststructurallyinclined history of the politics of the French Revolution as a major breakthrough insuring that, "Our reading of Marx and our understanding of class differentiation will never again be the same." 63

Whatever the merits of Scott's essays, they most emphatically do not contain a sophisticated interrogation of Marx and Marxist historiography or theory. Marxism is in fact caricatured in the pages of Scott's book, described as "a fixed set of definitional categories that must be applied to historical events in the same way every time." Engels's Origins of the Farnily is dismissed in a few lines and the only direct quote from Marx appears in a footnote and relates to the relationship of prostitution as the commodification of sexuality and the commodification of labour power. Scott misunderstands the work of Juliet Mitchell and assumes that her defence of the psychoanalytic tradition must somehow be dichotomized from materialist analyses of gender when in fact Mitchell's work is a sustained effort to explore the materiality of the unconscious. ${ }^{64}$ To appreciate the impact of Scott, then, it is necessary to look in directions other than those that relate to a substantial appreciation of Marxism.

Scott's appeal lies in her timely elaboration of gender as a useful category of historical analysis. She provided a summary of the literatures and positions consolidating around gender at precisely the moment that historians were in need of moving beyond narrative stories of women's involvement in history. The very necessity of those stories testified to the process of exclusion that was characteristic of historical practice throughout most of the twentieth century. In doing this, Scott provided no fundamental theoretical restructuring of women's experience or gender relations, but summarized the developments within social history and feminist theory up to the early 1980s. Politically, Scott lent this project her professional reputation, detailing as well the experience of women in the American University. These narrations of a process of silencing and the attempt to break out of it with written histories and concrete involvement in the academic job market were, however, presented alongside of a parallel commitment to poststructuralism as a theoretical agenda that would empower women through its capacity to address discursive identities long suffocated under the weight of patriarchal power. Scott grasped poststructuralism, especially Derridean deconstruction and Foucauldian approaches to knowledge as power, as keys capable of unlocking a closed historiographic door. To make her point she took to task Thompson's Making and its gendered - masculinized - notion of class ${ }^{65}$

The result is not so much a powerful indictment of Thompson's text as it is an indication of how poststructuralism, in the hands of those paying lipservice to its premises, can simply provide theoretical window-dressing for projects that have no need of it or, worse, collapse inward in a politics of dubious character. Thus Scott has some useful things to say concerning the ways in which class was metaphorically gendered in the language of Jacobinism, just as she explores with sensitivity the extent to which statistical representations of work in nineteenth-century Paris constructed the meaning of labour in gendered ways. As insightful as these and other points are

63 Dustjacket promotional statement on Joan Wallach Scott, Gender and the Politics of History (New York 1988).

64 Scott, Gender and the Politics of History, 69, 35, 223, 207.

65 For a detailed discussion see Palmer, Descent into Discourse, esp. 78-86. 
they hardly require the theoretical foundation of poststructuralism to shore them up. What does get erected on that foundation, however, is a troublingly aestheticized politics. Historically this collapses into an oddly essentializing opposition, in which the fantastic prophet Joanna Southcott serves as an example of sexual difference, domesticity, and spirituality, while Mary Wollstonecraft and others are in Scott's terms little more than "fitting partners for Radical men," their secular, combative, and rational make-up being little more than a cosmetic politics of accommodation. ${ }^{66}$ This fixation on sexual difference as the pivot of politics translates into Scott's insistence that women struggling in the courts to fight inequality and wage discrimination would do well to arm themselves with the works of Derrida and Foucault. This aestheticization of politics in the name of a poststructuralist understanding of gender has led one commentator to remark: "It defies common sense to think that a fully articulated deconstructive position, presented in the language of academic theory, would ever persuade a reactionary judge to rule in favor of women claiming discrimination.... The message seems clear: Cherchez la femme and leave real women on the side." 67

What the problematically undertheorized poststructuralism of Scott's work exposes is the tendency for a feminist analytic postmodernism to collapse inward on the very same troubling oppositions and essentialisms it supposedly decrys. Adept at pointing to the tendency of particular social formations to construct women categorically, and then to extend that construction into widening spheres of power and authority, thus imposing gendered understandings on whole realms of seemingly 'neutral' relations within civil and economic society, poststructuralist feminism has the decided tendency to stop the analytic exercise at this point, reifying the almost Weberian ideal typologies of women, and failing to explore the actual diversity of the history of gender relations. ${ }^{68}$ In short, poststructuralist feminism, proclaiming the materiality of representation, denigrates the material as merely representational. Class, surely a social relationship and structural presence made as much historically and economically as it is forged in language, image, and rhetoric (however much these forces are indeed interrelated), inevitably gets shunted aside in explorations of the past resting theoretically on this feminist poststructuralism, or, as in the case of Joyce, the material meaning of class is constantly dodged in a project that can only be understood as analytic waffling. Two recent much-acclaimed feminist social histories of English Canadian experience premised on a loose reading of poststructuralist theory illustrate features of this historiographic tendency.

Mariana Valverde's stimulating study of moral reform in the 1885-1925 years opens with an explicit bow to poststructuralist thought: "A crisis of confidence is currently affecting both of the disciplines informing the intellectual context of this book, namely history and social theory. Historians, particularly social historians, are now asking themselves whether the traditional tasks of gathering facts and reconstructing the past are not perhaps somewhat illusory, given the findings of linguistic theory, discourse analysis, and studies in the sociology of knowledge." Among the few authors cited on the first page of this "Preface" are, predictably, Gareth Stedman Jones and Joan Wallach Scott. Concerned with the orchestration of metaphors and allegories that aimed to morally and sexually regulate a people, Valverde provides

66 Scott, Gender and the Politics of History, esp. 78

67 Claudia Koonz, "Post Scripts," The Women's Review of Books, 6 (January 1989), $20,19$.

68 This, I would argue, is precisely the strength and the weakness of Denise Riley, Am I That Name: Feminism and the Category of 'Women' in History (London 1988). 
an exciting account of the "slippages" of the reform agenda: of how a discourse on race or immigration contained subtexts that we can read in class or gender terms; of the ways in which moral panics, ostensibly about matters seemingly sexual, might well congeal, in the popular unconscious as well as in more manipulative orderings, different discourses in a single image. She explores the reform milieu and its personalities, providing Canadian historians with a new reading of 'the social problem' as it was lived in a time of intense questioning and considerable social and economic turmoil. ${ }^{69}$

A full assessment and appreciation of Valverde's book would necessitate acknowledgement of her many accomplishments, most directly her capacity to expose us to the ways in which life was not lived out in the past as a series of separations. In insisting on the totality of experiences too often demarcated as distinct, Valverde draws us into the connections of the sexual and the economic, of sin and the slum, of private and public, of morality and politics. She breathes new interpretive life into a subject too often forced into analytic cul-de-sacs. That said (and this praise is too truncated), it is nevertheless the case that Valverde's book, like Joyce's Visions of the People, exposes some of the difficulties of an eclectic use of poststructuralist thought. If Joan Wallach Scott might be considered poststructualism's evangelical feminist proselyte, Valverde is more its pragmatic advocate, drawing on theories and perspectives somewhat casually.

This results in a classic case of fence sitting with respect to the questions revolving around causality and class. Indeed Valverde presents her text sandwiched between two statements of illuminating contrast:

readers who see that feminist history is more important than women's history and who know that feminist history is about gender, not women, will perhaps be disappointed that the analysis claims that class, and more often race, was in many instances a more important social contradiction than gender even when women and sexuality are overtly the topic of concern.

we have seen that race, gender, and sexuality are best understood not as secondary, adjectival features of class subjects but rather as relatively autonomous categories that can be constructed and experienced as more basic than class.

Small wonder that in her conscious distancing of herself from the economism of those Marxist commentators on the Canadian state who neglect sexual and moral regulation, Valverde herself avoids the more overt material might of state power. ${ }^{70}$

In the same years Valverde studies, the state was not only assimilating the discourses of the Anglo-Saxon social purity movement, but also sending troops and gatling guns into striking mining communities, constructing an increasingly elaborate labyrinth of industrial legality meant to contain class conflict, orchestrating mass deportations of radical 'aliens', crushing proletarian revolt in 1919, and furthering and deepening the logic of capitalist accumulation through policies and practices that concentrated economic ownership of manufacturing and resource industries. ${ }^{71} \mathrm{I}$ am not suggesting that Valverde's project of exploring the moral and sexual dimension of the regulatory state must, on every page, allude to the primacy of economic

69 Mariana Valverde, The Age of Light, Soap, and Water: Moral Reform in English Canada, 1885-1925 (Toronto 1991), quotes from 9, 13.

70 Valverde, Age of Light, Soap, and Water, 12, 166, 44.

71 The literature that could be cited here is immense. See, for a synthetic statement Bryan D. Palmer, "The Remaking of the Working Class and its Oppositions, 1895-1920," in Working Class Experience: Rethinking the History of Canadian Labour, 1800-1891 (Toronto 1992), 155-213. 
determination. Rather, it is striking that a text premised on the "slippage" of categories such as class, race, and gender into one another, cannot appreciate the "slippage" of "moments" of regulation - moral, sexual, economic, ideological - as well.

Valverde's "toolkit" of theory is thus not as eclectic as it might well be, for while she walks the interpretive ground of "regulation" she ignores the French regulation school which has done so much to identify the Fordist regime of capitalist accumulation that came into being at much the same time as moral reform swept Canada. ${ }^{72}$ French theory is thus embraced by Valverde at the point of Foucault but not Aglietta: concerned with a poststructually legitimated "ethical subjectivity," Valverde seems almost oblivious to the blunt physical histories of collectivities ruled, not ethically, but through force, whatever its masks. She also bypasses the interpretive signposts offered by Gramsci's abbreviated and hurriedly-formulated notes in "Americanism and Fordism," a curious omission given the Italian Marxist's overt attention to sexuality, "animality," and the country versus the city opposition. Surely when Gramsci called attention to "the increased moral coercion exercised by the apparatus of the State and society on single individuals, and of the pathological crisis determined by this coercion," he was on the same subject ground as Valverde. ${ }^{73}$ One wonders, for instance, in the absence of Valverde actually examining the prostitutes themselves (it is prostitution as symbol that is central to her text) and their subjection to legal and socio-economic ostracism, how powerful the reform image of these women as "running sores" on "the human family" was as a social construction of constraint? Compared to gendered labour markets, the law, the police, the dangers of the street, and the intimidations of madames (pimps not yet being a major social force in the sex trade), the "work of allegories" may well have paled in material significance before other powerful inhibitions.

It is difficult not to read Valverde's account of moral reform, then, as a failure not to transcend the ideology of the age and connect more directly the representation of vice and social decay to the direct and obvious class needs of a state that propogated images at the same time as it protected profit. In this sense its waffling on the question of class is quite similar to that found in Joyce's Visions of the People and, in all likelihood, the reasons for this waffling are to be found in a poststructurally-informed rejection of Marxist understandings of class and its meanings, which extend into the realm of ideology, a term Valverde would undoubtedly react to with adversity.

Valverde's sweep across the textual experience of moral reform regulation, with its attentions rivetted on the rhetoric and leading figures in the social purity movement rather than on the subjective histories of the objects of this crusade, contrasts with Joy Parr's attempt to get inside the lives of women and men in two small industrial towns in the central Canadian province of Ontario in the first half of the twentieth century. Valverde's work might well be designated a text of historical sociology; Parr's study is most emphatically social history. The Gender of Breadwinners has received universal praise in Canadian historical circles, applauded for its original research, innovative feminist analysis, and reconstruction of the familial and work-

72 For an introduction see Michel Aglietta, A Theory of Capitalist Regulation: The US Experience (London 1979); and for a statement drawing on this in limited ways, Mike Davis, Prisoners of the American Dream: Politics and Economy in the History of the US Working Class (London 1986). Useful critiques are found in Robert Brenner and Mark Glick, "The Regulation Approach: Theory and History," New Left Review, 188 (July/August 1991), 45-119; Mike Davis, "'Fordism' in Crisis: A Review of Michel Aglietta's Regulation et crises: L'experience des Etats-Unis', Review, 2 (Fall 1978).

73 Antonio Gramsci, Selecions from the Prison Notebooks (New York 1971), 279-318, quote from 280. 


\section{2 left history}

place contexts of a period central to the formation of the modern Canadian labour movement.

Parr's reconsideration of capitalist transformation rests unambiguously on the support of a feminist theory indebted to "the recent post-structural critiques of the categoricalism within which the study of class and gender relations in industrial society has been framed." Wary of Marxist, neo-classical, and radical feminist tendencies to assign an 'ahistorical master category' pride of interpretive place, Parr embraces the usual poststructuralist call for an interpretive end to all ordered oppositions: "We need to problematize and unmake the chain of binary oppositions - masculine/feminine, market/non-market, public/private, waged/non-waged and rethink the categoricalism that cantonizes gender, class, race, ethnicity, and nationality, so as to see past the conceptual signage, which has illuminated the previously invisible but now threatenes to obstruct our view of the living space beyond."74

What follows from this clearly stated poststructuralist agenda is rather odd. Out of the commitment to break down opposition comes a text that turns on fundamental dichotomies. Parr constructs a history of gender and work for wages that constantly places one "reality" in opposition to another: of her two locales of study one, Hanover, a furniture-producing community, is a men's town, its social relations and contests turning on male skill and breadwinner status; the second physical setting, the woman's town of Paris, is a site of textile manufacture in which women found waged employment and the liberating freedoms that came with breaking the shackles of domesticity and dependency. The historical evolution of these distinct and different places is presented with richness and imagination, but the poststructuralist promise to fight free of master categories and binary oppositions is little more than a rhetorically 'correct' gesture. Gender is here the new master category and while it reveals much - and the study is to be valued for this - it obscures a great deal as well.

With Parr's subtle displacement of class through the focus on gender relations, she manages to avoid the analytic problem of ultimate economic power: of who ruled in Paris. If this was truly a women's town, the answer would be obvious. But the women's town of Paris was, in fact, a classic paternalistic milltown, dominated spatially by the textile buildings, symbolically overseen by the owner, John Penman, whose gothic domicile, dubbed Penmarvian, overlooked the community from the heights of 'Quality Hill'. Penman financed a night school, dispensed charity, paid for the educations of local youth, kept his hand in the Young Men's and Women's Christian Associations, endowed the Presbyterian church, sponsored leisure activities for the workers and, incidentally, controlled almost entirely the local labour market, paid low wages and did an effective job of keeping the mills free of pernicious unionism. Mill officials were prominent in civic politics, and many thought that they used their influence there to insure that the Penman enterprise retained a lock on dispensing jobs in the town by keeping other factories out. Parr rejects such a view, choosing to ignore the voices of residents and Penmans employees about the power of corporate capital, instead explaining the one-industry, one-firm dominance by recourse to a geographical/property determinism in which "topography and pre-existing land title had determined that industrial diversification in Paris would be slight." 75

74 Joy Parr, The Gender of Breadwinners: Women, Men, and Change in Two Industrial Towns, 1880-1950 (Toronto 1990), esp. 6,8. 
In skirting the extent to which a women's town could exist amidst such stark dominance of a particularly paternalistic capital, Parr elevates the power of gender by limiting its meanings. When the focus is on the habits of the home, and the extent to which the material relations of wives, husbands, and unmarried females were ordered by women's access to the wage, Paris may well seem a women's town. Parr promotes her book as fulfilling the urgings of Virginia Woolf: "Let us not take it for granted that life exists more fully in what is commonly thought big than in what is commonly thought small." She obviously relates this admonition to the need to study the specifics of small towns such as Paris and Hanover. But it also appears that The Gender of Breadwinners turns less on this geographical pivot than on a theoretical project of investing gender and class with meanings that avoid the large questions of power, authority, and the wielding of public, as opposed to private, control. Parr thus sidesteps the interrelationship of public and private life with an appreciation of the public that deflates ultimate political and economic power and an understanding of the private realm that inflates the significance of the small advances that, however important domestically, failed to alter the structures of dominance and subordination. ${ }^{76}$

This is fundamentally a matter of class rule, the presence of which is obvious from Parr's evidence, but overshadowed by her interpretation. Consider, for instance, how she presents the major class confrontation of the entire period of her study, a 1949 strike at the Penmans mill that is widely acknowledged to have split the community and cut itself into the very bone of popular memory and social allegiance. Led by communist organizers from outside the area, waged as one of the opening shots in a domestic Cold War, pecipitating Paris as a small enclave into the national limelight, the strike was a bitter one-hundred day battle that saw male and female strikers fighting for a union they were not to get. Marshalled against them were the forces of capital and the state, with police, courts, and certification procedures stacking the deck against the local working class and major Ontario newspapers suffocating the struggle in endless denunciations. Parr provides a stimulating account of the imagery of the conflict, especially the representation of womenly militance as a case study in feminine wiles and the masculinist stand of the outside organizers. But in the end she is not really interested in the events of the actual record of class combat. Indeed, she would deplore such a military metaphor. Instead, Parr uses the strike as a backdrop, against which she explores "the ways in which the ideologies of gender, class, and community limited, edited, and vanquished what happened in Paris...." The class struggle has become a text, and its unfolding a dramatic discourse. Parr reads the final page of this narrative, which ends on a note of defeat, as indication of "local distrust of class-based actions as a way to bring about social change"; the workers of Paris were poststructuralist years ahead of their time. Parr concludes that these mill labourers were "disheartened by a renewed awareness of their limitations," and that they turned "back for meaning in their lives to the gender- and community-based solidarities in which their militance had been forged." 77

This comes not so much as a statement of interpretation - for it lacks any substantive evidence - but as an authorial endorsement. But what was the Paris

75 Parr, Gender of Breadwinners, 36-40. Conversant with much of the international literature on milltowns, Parr is nevertheless surprisingly uninfluenced by Joyce's exploration of paternalism in Work, Culture, and Politics.

76 Parr, Gender of Breadwinners, 11.

77 Parr, Gender of Breadwinners, 97, 119. 


\section{4 left history}

community, if it was not Penman's community, a 'reality' evident in the crushing of class militance? How were the gender solidarities of small-town Ontario in the 1950s lived, if not, in part, as the confinements of the 'feminine mystique'? ${ }^{78}$ Can we understand the large societal relations of oppression and exploitation through this narrowed focus, out of which emerges a precarious analytic balancing act $?^{79}$ The Penmans firm offered a blunt and appropriately hard-edged answer to all of these questions in the 1980s. After roughly a century of extracting surplus from the workers of the town, it closed the mill doors for good. A women's town, such as it was, ceased to exist when the masters of a class society deemed it no longer a profitable site of exploitation.

Stedman Jones, Joyce, Scott, Valverde, and Parr thus stand as particular signs of the times. They are representative of the extent to which a poststructuralism that situates itself in problematic ways to historical materialism and its understandings of class and ideology has insinuated itself into the project of interpreting the past. Marxists given to structuralist and aestheticized stands, social historians uncomfortable with the Marxist insistence on determination, and feminists of various kinds have all found something to embrace in the eclectically proliferating theoretical implosion of poststructuralism. Much of value has indeed come out of this project. Postructurally inclined historians rightly stress the need for closer attention to language and representation, demand scrutiny of the unreflective construction of analytic categories within the master codes of dominant ideologies both past and present, and justifiably call for research into the discursive identities that surround the social space of class and consciousness. No Marxist should react in blind opposition to this kind of challenging expansion of the terrain of study and explanation.

But as the commentary on the above texts indicates, historical materialism is not incapable of addressing these issues. Indeed, it is apparent that only with Marxism's analytic insistence on material referentiality can the free-fall of poststructuralism into an ideological rationale of postmodernity's continuous, albeit agitated, connection to capitalist forms of exploitation and oppression be halted. Stedman Jones and Joyce, for instance, may well present important findings of the languages of class and its limitations, but it requires the hard labours of historical materialist theory and empirical research to explain just why it was that class consciousness could not break through the actual walls of political thought, dialect, sectional trade attachments, and the dialogues of music hall ballads and popular broadsides. The answers to the dilemmas of class as a process of consciousness lie not in divorcing the material place of labour from its conception of itself, as Stedman Jones and Joyce are prone to do, but rather in excavating that structure of being to better understand and materialize the structure of feeling that at times accompanied it, at other times seemed strikingly out of step ${ }^{80}$ That their project rejects this balance is a product of the politics of

78 Betty Friedan, The Feminine Mystique (New York 1963).

79 Parr concludes The Gender of Breadwinners on this note: "Neither manliness, nor womanliness, worker nor boss, native nor newcomer was a unitary condition; each comprehended diverse possibilities and practices. Sometimes within the tight grip of a triumphant ideological prescription, sometimes out of hand and incidentally free from its grasp, both power and oppression were framed in this unsettled and unsettling contention, always more, often very different, in the whole than they might appear to be by parts." (245-46) To nod in agreement with this kind of statement of heterogeneity is almost required in our times. But after all the nodding is done, might not someone ask, impolitely, 'What does this mean?'

80 This I take to have been the project of Raymond Williams. For an introduction see Keywords (London 1976); Politics and Letters: Interviews with New Left Review (London 1979); Problems in Materialism and Culture (London 1980); The Politics of Modernism: Against the New Conformists (London 1989). 
postmodernity, of disillusion and despair, on the one hand, and of proud anti-Marxist defiance, now finally legitimated by 'theory', on the other.

This, too, is central to feminism's varied responses of rejection of the Marxist project. But feminist theory and historical writing also needs, desperately so, the checks of historical materialism if it is to work its way through the fundamental dilemmas of its own making. ${ }^{81}$ For as the range of postructurally-informed writing on class and gender suggests, feminist histories that take the ideological cues of the postmodern age as a theoretical guide find themselves at best waffling on the question of class and, at their worst, caught up in the massive contradiction of repudiating the essentializing category woman at the same time that they reproduce it in their pages, denying the concrete validity and meaning of binary oppositions as they are embedded in Western thought only to recast them as lived experience. ${ }^{82}$

There are those feminist theorists who are resisting this movement, at the related levels of theory, interpretation, and politics. ${ }^{83}$ But the drift of the last decade has not been in this direction. Michèle Barrett's introduction to the 1988 edition of Women's Oppression Today captures the trajectory of feminst theory over the course of the 1980s. Once committed to Marxism and materialist analysis, the Barrett of the late $1980 \mathrm{~s}$ is a captive of the ideological ensemble of poststructuralist theoretical positions associated with the supposed political and cultural ruptures of postmodernity:

post-modernism is not something that you can be for or against: the reiteration of old knowledges will not make it vanish. For it is a cultural climate as well as an intellectual position, a poltical reality as well as an academic fashion. The arguments of postmodernism already represent, I think, a key position around which feminist theoretical work in the future is likely to revolve.... I want to add a word about the general philosophical climate of today in comparision with the one that informed the book's premises. Just as it would be impossible to write such a book without integrating a consideration of racism and ethnicity, so it would, I think, be impossible to write in such a confidently materialist vein. At the very least one would have to defend the assumptions made about epistemology, the concept of ideology, the purchase of Marxist materialism, and the definition of the subject. Thus there would have to be a consideration of whether, for example, Foucault's suspension of epistemology and substitution of 'discourse' and 'regimes of truth' for a theory of ideology was to be accepted or not. There would have to be a consideration of arguments, put forward by Ernesto Laclau and Chantal Mouffe, that the substantive arguments of a Marxist analysis of capitalism must be superseded. There would have to be an engagement with the arguments that the theory of the subject embodied in the text was, whilst not the universal male identification of bourgeois ideology, nevertheless still a conception unacceptably tainted by a humanist perspective. ${ }^{84}$

81 The work of Juliet Mitchell is just such an attempt to take the valuable insights of feminist theory such as attention to the subject and to the importance of the personal - and materialize them. But her early work on psychoanalysis remains anathema to many feminists convinced that Freud is, simply put, the enemy; her later call to appreciate economic determination and limitation has been misconceived as retreat. See Juliet Mitchell, Psychoanalysis and Feminism: Freud, Reich, Laing, and Women (New York 1974); "Reflections on Twenty Years of Feminism," in Juliet Mitchell and Ann Oakley, eds., What is Feminism? (Oxford 1986), 34-49.

82 In "Feminism, Humanism, Postmodernism," Troubled Pleasures, 228-245, Kate Soper offers a way out of this dilemma, but it is not one embraced by many poststructuralist feminist theorists or historians. For an approach of feminist literary theorists to the problem of essentialism see the volume of Tessera, 10 (Summer 1991) devoted to this issue.

83 See, for instance, the underappreciated Lynne Segal, Is The Future Female? Troubled Thoughts on Contemporary Feminism (London 1987); Segal, Slow Motion: Changing Masculinities, Changing Men (London 1990). 
Passages such as this return us, but in new ways all the more threatening, to historical materialism, to the ground of "The Poverty of Theory."

\section{The Irony of Ideology}

The Marxist literary critic Franco Moretti has insisted that a century of modernism has taught us that "irony, extraordinary cultural achievement though it is, has to recover some kind of problematic relationship with responsibility and decision - or else, it will have to surrender history altogether." ${ }^{166}$ Edward Thompson said much the same thing decades earlier when he stressed the importance of the "consequences of consequences" and the need to understand the contradictory character of human development, in which "opposing tendencies and potentialities can interpenetrate within the same tradition." This he saw as "the stuff of history." ${ }^{87}$ In this concluding section I want to address these questions of irony, responsibility, and the consequences of consequences, not in order to apportion blame but to understand the ironic authority of poststructuralism as the ideology of postmodernity, especially as this pertains to the practice of historical materialism.

For it is my contention that the fundamental advances of historical materialist historiography were registered throughout the 1960s and 1970s, ironically, in ways that have filtered through the class defeats and disillusionments of our time, only to be refiltered, as a consequence of this separation of theory and practice, through the ideological prism of postmodernism in the 1980s and 1990s. The result is an ironic but understandable set of reversals, registered as 'theory', but in fact comprehensible - in terms of a political project of changing the world as opposed to glorying in its ever more complex interpretive possibilities - as retreat. This was not necessarily the fault of those historical materialists of an earlier generation but was, instead, a 'theoretical' end overdetermined by a series of necessary political refusals that failed, by and large, to be followed by positive political developments capable of generating the kind of practical Marxist endorsements that could relight the cooling embers of the theoretical fires of historical materialism. When these fires burned less brightly in the suffocating darkness of the political defeats of the late twentieth century, the epoch of postmodernity was there to be proclaimed as a new dawn, the ideology of poststructuralism raining down on them in a steady and dampening drizzle.

To understand this process it is necessary to return, once again, to Thompson's "Poverty of Theory," for it was this text that reiterated that the theoretical rupture within historical materialism that produced The Making of the English Working Class and a host of other important writings was, in its origins, a political rupture, symbolized by "1956," fiercely oppositional to Stalinism. It was in that moment of Marxist reassessment and realignment that Thompson and others, such as John Saville, articulated the need for a socialist humanism that would stand as stark contrast - theoretically and practically - to the moral nihilism, anti-intellectualism, and denial of the creative agency of human labour and the value of the individual that

84 Michèle Barrett, Women's Oppression Today: The Marxist/Feminist Encounter (London 1988), xxxiii-xxxiv. Discerning readers will note that although Barrett did not alter her text she did change her subtitle. Originally published under the heading "Problems in Marxist Feminist Analysis," the reprinted edition proclaims itself a text in "The Marxist/Feminist Encounter." This is a fair distance to travel in eight years.

85 See Kate Soper, "The Socialist Humanism of E.P. Thompson," in Troubled Pleasures, 89-125.

86 Franco Moretti, Signs Taken for Wonders: Essays in the Sociology of Literary Forms (London 1988), 248.

87 E.P. Thompson, "Agency and Choice," New Reasoner, 4 (Summer 1958), 106. 
many claimed 1956 exposed as fundamental to Stalinism. Theoretically, Thompson translated this political break into a direct repudiation of the base/superstructure metaphor central to orthodox Marxism. He saw the crude determinism of this dichotomized coupling, with its ideological caricature of conscious human agency as nothing more than a reflection of men's social being, as a political rationale for Stalinism and a theoretical justification for historical materialist writing that reduced class formation to the equation of so many factories + so many peasants driven from the land $=$ the proletariat ${ }^{88}$ Concerned with the silences in Marx, and the subsequent reproduction and indeed legitimation of those silences in Marxist historiography, Thompson conceived of The Making of the English Working Class as an extension of Marxism, as a rehabilitation of "lost categories and a lost vocabulary," an attempt to find a voice for the "unarticulated assumptions and unrealized mediations" of an actual experience Marx too often bypassed in his engagement with the terrain and categories of bourgeois political economy. ${ }^{89}$

Out of this rupture - simultaneously political and theoretical - Thompson offered his historical writings of the 1960s and 1970s, in which class formation was never simply collapsed into the formulae of economism but, rather, lived out at the intersection of agency and structure as a web of determination that set the limits of what was possible, limits within which society and economy, culture and politics, developed and changed. Three points, however, need be remembered and placed alongside of the developing edifice of what has been called 'socialist humanist history'. ${ }^{90}$

First, Thompson always conceived of the project of historical materialist histories as a collective endeavour: growing out of the collaborations of the British Communist Party Historians Group, this project was never meant to produce all-encompassing texts; rather, it was comprised of different writings and, above all else, differing historical sensitivities and differing tones of presentation, most especially those associated with a more closely economic argument. For Thompson, his own writings were always to be placed alongside those of others, such as Hill, Saville, Dorothy Thompson and, even, the one major historian who remained loyal to the Party after 1956 , E. J. Hobsbawm. ${ }^{91}$ Parallel to this grouping, Raymond Williams was increasingly to address theoretical issues central to Thompson's project, albeit in a language more congenial to orthodox Marxism. ${ }^{92}$ Second, while unambiguously hostile to the notion of base/superstructure, Thompson never abandoned the notion of economic determination. In the last instance, as it were, he remained very much the materialist. "I hope," Thompson stated clearly in 1978, "that nothing I have written above has

88 See, for instance, E.P. Thompson, "Socialist Humanism: An Epistle to the Philistines," New Reasoner, 1 (Summer 1957), 105-43; Bryan D. Palmer, The Making of E.P. Thompson: Marxism, Humanism, and History (Toronto 1981); Ellen Meiksins Wood, "Falling Through the Cracks: E.P. Thompson and the Debate on Base and Superstructure," in Harvey J. Kaye and Keith McClelland, ed., E.P. Thompson: Critical Perspectives (Philadelphia 1990), 125-152; "Interview with E.P. Thompson," in Henry Abelove, et al., Visions of History (New York 1983), 3-26.

89 "Interview with Thompson," Visions of History, 21; Thompson, "Poverty of Theory," 251-252.

90 Richard Johnson, "Thompson, Genovese, and Socialist Humanist History," History Workshop Journal, 6 (Autumn 1978), 79-100.

91 See, for instance, Eric Hobsbawm, "The Historians' Group of the Communist Party," in Maurice Cornforth, ed., Rebels and their Causes: Essays in Honour of A.L. Morton (London 1978), 21-48; "Interview with Thompson," Visions of History, esp. 22.

92 See, for instance, Raymond Williams, "Base and Superstructure in Marxist Cultural Theory," New Left Review, 82 (November-December 1973), 3-16; Williams, Marxism and Literature (London 1977), esp. 75-89. 
given rise to the notion that I suppose that the formation of class is independent of objective determinations, that class can be defined simply as a cultural formation." ${ }^{.93}$ Third, as this engagement with Marxist theory and historical materialism developed, a New Left Thompson had helped to initiate drifted increasingly in directions he deplored. In these years the aestheticization of British Marxism paved the way for the Althusserian structuralism he would later pillory in "The Poverty of Theory." Alongside the historical materialist advances of Marxism as history, Marxism as a political practice registered no corresponding victories, an interpretive point of agreement shared, interestingly, by both Thompson and Perry Anderson. ${ }^{94}$ Some on the left saw this aestheticization rampant enough to decry the rise of "a coterie of marxist swots at the mercy of their own intellectual crazes, and prizing theory more as evidence of their own cleverness than for its possible relevance in the struggle for socialism." 95

Indeed, this kind of overly harsh dismissal of the trajectory of those Perry Anderson gathered around him at the new New Left Review, a journal Thompson, Saville, and others helped to found only to find themselves rather quickly displaced, had early been thrown in the face of Thompson himself by the Trotskyist Peter Fryer. Fryer, like Thompson, made his exit from the Communist Party in 1956, but he refused to follow Thompson in his insistence that Stalinism was linked to Lenin's base/superstructure derived understanding of knowledge as a reflection of being. This comprised, for Fryer, "an assault on the philosophy of dialectical materialism" leading "into the swamp of subjectivism and solipism."

It is the ironic conclusion of this essay that while Fryer's assessment of Thompson was wrong and one-sided, it nevertheless speaks to the authority of poststructuralism as the ideology of the contemporary postmodernist moment. Lacking the disciplined connection to Marxism as a political practice that had, in good measure, constructed Thompson and others as dissident leftists, many historians who came to maturity in the New Left mobilizations of the 1960s and early 1970s experienced their leftism as - a further irony - culture rather than as politics. Their staying power as leftists, as well as their discipline as Marxists, was in no way comparable to those of Thompson and his generation. As Thompson notes in "The Poverty of Theory," whatever the battles waged and remembrances of struggles past fondly recalled, "there has never been a generation of socialist intellectuals in the West with less experience of practical struggle, with less sense of the initiatives thrown up in mass movements, with less sense of what the intellectual can learn from men and women of practical experience, and other proper dues of humility which the intellect must owe to this." Any sense of current critical theory and Marxism thus commences, for Thompson, "with a de facto sociological and intellectual segregation of theory and practice." $" 97$

This is, as the history of Western Marxism has shown for much of the twentieth century, a heavy burden to shoulder. Given the immense class defeats of what has been passed through of the last quarter of the twentieth century - from the implosion

93 E.P. Thompson, "Eighteenth Century English Society: Class Struggle without Class?" Social History, 3 (May 1978), 149.

94 Thompson, "Poverty of Theory," 376; Perry Anderson, Arguments within English Marxism (London 1980), 150.

95 Peter Sedgwick, "The Two New Lefts," in David Widgery, ed., The Left in Britain, 1956-1968 (Harmondsworth 1976), 131-153.

96 Peter Fryer, "Lenin as Philosopher," Labour Review, 2 (September-October 1957), 136-147.

97 Thompson, "The Poverty of Theory," 376. 
of the first workers' state to the bellicose triumphalism of a reinvigorated American imperialism evident in the grotesquely one-sided waging of war in the Gulf to the New Right-orchestrated assault on western trade unionism crippled by economic restructuring - this weight is made all the more onerous. In this political context many social historians have assimilated Thompson's message of the silences in Marx and in historical materialism, but they have done so on an entirely different political terrain. The result is that a two-sided engagement with Marxism, rooted in a passionate rupture from Stalinism that refused, categorically, to succumb to the capitulationist ideology - evident in the movement away from Communism of a previous generation associated with Koestler and 'the God that failed' - of capitalism in its ascendant years of the mid-twentieth century, has become decidedly one-sided at the end of the century.

This one-sidedness has indeed taken on some of the character of, in Fryer's words of the late 1950s, a swamp of subjectivism and solipism. Many social historians drawn, however cavalierly, to critical theory, deconstruction, and discourse have historically passed through a 'Thompsonian' moment or continue to rationalize their repudiation of historical materialism and class through recourse to what they designate the insights of Thompsonian texts. This is no fault of Thompson himself, who did what he could with "The Poverty of Theory" to stem the tide of "idealist irrationalism" and, subsequently, has offered a Swiftian satire addressing pointedly the follies of the reification of language. ${ }^{98} \mathrm{But}$ the process exposes how a particular consequence of a specific political and theoretical motion can, in an entirely different milieu and in the hands of a markedly divergent appreciation of experience and its meanings, result in consequences that reverse direction and stall, if not stop, specific developments.

Evidence of this particular process among social historians is now abundant, surveyed through the pages of the History Workshop Journal by a Raphael Samuel who displays a curious apolitical resignation to what seems to him a kind of intellectual overdetermination. Refreshing in its range and idioysncracies, Samuel's historiographic commentary concludes on a note strikingly congruent with the argument of the centrality of Thompson and the ruptures of 1956:

Discourse analysis, as practiced by the French post-Marxists and their latter-day American followers, is another way of writing about the social order. In the hands of Foucault himself, a wayward but inspired historian, posing as a theorist, it is a kind of Marxism without the economics. His 'discursive formations' are base and superstructure, theory and practice rolled into one... Foucault refuses the Marxist notion of ideology and distances himself from the idea of general theory.... His 'epistemes' evidently involve both a master signifier and a community of meanings; his 'discursive formations' are by definition cultural wholes....The insistence on radical heterogeneity goes hand in hand with a considerable appetite for the identification of the generic; for the reconstitution of symbolic essences...and for the designation of transhistorical, or meta-historical forces.

Given the language of this passage one can be excused for mistaking its author for Hayden White, and substituting Thompson for Foucault. But that would err seriously, as Samuel well knows, for in Foucault "class [has]....been dismantled as a collective subject,...its place taken by a whole series of unified categories which serve as the

98 Thompson, "The Poverty of Theory," 384; Thompson, The Sykaos Papers (New York 1988) and, for comment on this later text, Palmer, Descent into Discourse, 211-214; Paul Buhle, "Isn't It Romantic: E. P. Thompson's Global Agenda," Voice Literary Supplement, 76 (July 1989), 24-26. 
common currency of critical discourse. ${ }^{.99}$ With the refusal of this jettisoning of class we are back, once again, with "The Poverty of Theory."

The pages of History Workshop are as good a place as any to locate the historiographic fashion of the moment. On American campuses, writes Irving Howe, what we are witnessing today "is a strange mixture of American populist sentiment and French critical theorizing as they come together in behalf of 'changing the subject'." Reminiscent of Joyce's Visions of the People, Howe concludes that, "The populism provides an underlying structure of feeling and the theorizing provides a dash of intellectual panache." As Bruce Robbins comments in an extension of Howe's claim, class is what has been lost in this subjectivist shuffle. ${ }^{100}$ But as Howe (and Russell Jacoby) well know, the populist appeal to the oppressed (which takes the form of addressing the subject as it is constructed in racial and gendered forms, but not as a class collectivity) is divorced from any substantive engagement with an audience let alone a mass political base precisely because its predominantly poststructuralist theoretical moorings are nothing if not a seductively sticky barrier inhibiting a politics of engagement and change. ${ }^{101}$

The ostensible, and much-proclaimed, end of Marxism is thus nothing more than a powerfully-orchestrated ideological mobilization. Historical materialism has lost neither its power to interpret the past nor its relevance to the contemporary intellectual terrain. What has happened, and undeniably so, is something quite different. The current political context is one of profound malaise for a left lacking in roots in political struggles. Situated at the historic conjuncture of the disintegration of what remains, after three-quarters of a century of Stalinist degenerations and deformations, of the workers' states of the Soviet Union, Eastern Europe, Indo-China, and the so-called Third World and the retreats of the labour movements of the capitalist West, this period presents a serious impediment to the project of extending the reach and purchase of historical materialism. These are not good times to be a Marxist.

Yet they are times when being a Marxist remains, arguably, of fundamental importance. For at no time in the history of the twentieth century has Marxism and the practice of historical materialism been on shakier ground; at no time has the threat to the practice of Marxism - political and theoretical - been so great. Marxist social historians will play, at best, a small role in the revival of a genuinely proletarian politics. But even a small role, in these times, is well worth playing. It will not be played, however, by adapting to the ideological climate of the moment. Historical materialism, as the post-1956 texts of Marxist historiography revealed, can indeed address silences in Marx's writing, but only if the audible accomplishments of Marx and subsequent Marxists remain. Poststructuralism is too often a reification of such silences, a reading of history and politics that throws these silences into the arena of interpretation and action the better to create a deafening din drowning out the voice of Marxism, the analytic sentences of historical materialism, the presence and capacity of class to speak. To keep the practice of historical materialism alive, to refuse to succumb to the current wave of subjectivism, but rather to reassert the

99 Raphael Samuel, "Reading the Signs," History Workshop: A Joumal of Socialist and Feminist Historians, 32 (Autumn 1991), 105-107. I have shifted the place of the last sentences in the block quote to enhance coherence. For White on Thompson see Hayden White, Tropics of Discourse: Essays in Cultural Criticism (Baltimore 1978), 14-19.

100 Irving Howe, "The Value of the Canon," The New Republic, 18 February 1992, 42, quoted in and commented on in Bruce Robbins, "Tenured Radicals, the New McCarthyism, and 'PC'," New Left Review, 188 (July-August 1991), 156.

101 Russell Jacoby, The Last Intellectuals: American Culture in the Age of Academe (New York 1987). 
necessity of historicizing and materializing both our analysis and activity as Marxists, will be no mean achievement in the years to come. Doing this can not help but contribute, in however limited ways, to the revival of a mass class politics of resistance that is the only force capable of turning back the destructive tides evident in both the intellectual and economic histories of our time. 